Review

\title{
Degradation and Aging Routes of Ni-Rich Cathode Based Li-Ion Batteries
}

\author{
Philipp Teichert ${ }^{1}$, Gebrekidan Gebresilassie Eshetu ${ }^{2,3}{ }^{\circledR}$, Hannes Jahnke ${ }^{1, *}$ and \\ Egbert Figgemeier $2,4, *$ (D) \\ 1 Volkswagen AG, Group Innovation, Letterbox 011/17774, 38436 Wolfsburg, Germany; \\ philipp.teichert1@volkswagen.de \\ 2 Rheinisch-Westfälische Technische Hochschule Aachen, Institut für Stromrichtertechnik und Elektrische \\ Antriebe, Jägerstraße 17-19, 52066 Aachen, Germany; Gebrekidan.Eshetu@isea.rwth-aachen.de \\ 3 Department of Material Science and Engineering, Mekelle Institute of Technology-Mekelle University, \\ Mekelle 1632, Tigrai, Ethiopia \\ 4 Helmholtz Institute Münster (HI MS), IEK-12, Forschungszentrum Jülich, Corrensstrasse 46, \\ 48149 Münster, Germany \\ * Correspondence: hannes.jahnke@volkswagen.de (H.J.); e.figgemeier@fz-juelich.de (E.F.)
}

Received: 20 November 2019; Accepted: 14 January 2020; Published: 22 January 2020

check for updates

\begin{abstract}
Driven by the increasing plea for greener transportation and efficient integration of renewable energy sources, Ni-rich metal layered oxides, namely $\mathrm{NMC}, \mathrm{Li}\left[\mathrm{Ni}_{1-x-y} \mathrm{Co}_{y} \mathrm{Mn}_{z}\right] \mathrm{O}_{2}$ $(x+y \leq 0.4)$, and NCA, $\mathrm{Li}\left[\mathrm{Ni}_{1-x-y} \mathrm{Co}_{x} \mathrm{Al}_{y}\right] \mathrm{O}_{2}$, cathode materials have garnered huge attention for the development of Next-Generation lithium-ion batteries (LIBs). The impetus behind such huge celebrity includes their higher capacity and cost effectiveness when compared to the-state-of-the-art $\mathrm{LiCoO}_{2}$ (LCO) and other low Ni content NMC versions. However, despite all the beneficial attributes, the large-scale deployment of Ni-rich NMC based LIBs poses a technical challenge due to less stability of the cathode/electrolyte interphase (CEI) and diverse degradation processes that are associated with electrolyte decomposition, transition metal cation dissolution, cation-mixing, oxygen release reaction etc. Here, the potential degradation routes, recent efforts and enabling strategies for mitigating the core challenges of Ni-rich NMC cathode materials are presented and assessed. In the end, the review shed light on the perspectives for the future research directions of Ni-rich cathode materials.
\end{abstract}

Keywords: Li-Ion battery; Ni-rich cathode; degradation; cathode-electrolyte interphase; electro mobility

\section{Introduction}

There is a growing necessity for reducing $\mathrm{CO}_{2}$ emissions to prevent further upsurge of the global temperature and, thereby, safeguard the fate of our planet and its occupants [1]. This calls for an urgent transition from the limited, as well as polluting, fossil fuels and internal combustion vehicles (ICEs) to renewable (e.g., solar, wind, etc.) energy sources and electro mobility (electric vehicles, xEVs) respectively [2,3]. 80\% of the transportation in USA and Germany is linked to on-road vehicles and, thus, moving towards electric vehicles (xEVs), offers the potential for emission saving. However, green energy sources are intermittent in nature and their proper utilization demands the use of highly efficient and durable electrochemical energy storage devices [4]. Similarly, xEVs necessities the use of high energy density batteries that are capable of negating the existing "driving range anxiety" [5]. Amid existing electrochemical energy storage devices, lithium-ion batteries (LIBs) have attracted huge attention as one of the most versatile and enabler devices for use in a wide range of applications. However, further improvements in the energy density of LIBs is urgently needed to meet the ever-growing stringent requirements for emerging large-scale systems. For instance, the electrical 
propulsion demands battery devices with high energy density allowing for the $\sim 500 \mathrm{~km}$ driving range

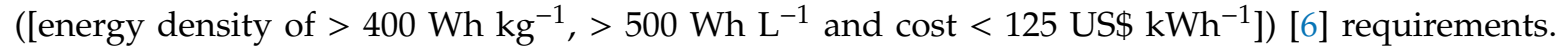
The energy density $\left(E_{c e l l}\right)$ of a given LIB cell is collectively determined by the discharge cell voltage $\left(V_{c e l l}\right)$ and Li-storage capacity $\left(C_{c e l l}\right)$, as shown in Equation $(1)[7,8]$, inferring an increase in the energy density of LIBs requires increasing both the cell capacity and maximizing the potential difference between the anode and cathode electrodes.

$$
E_{\text {Cell }}=\int V_{\text {Cell }} d C_{\text {Cell }}
$$

Owing to the fact that the anode materials offer a higher Li-ion storage capacity than the cathode, the latter presents to be the most important and limiting factor for the energy density of LIBs [9-12]. Following Sony's introduction of lithium cobalt dioxide $\left(\mathrm{LiCoO}_{2}\right)$-graphite cell in 1991, it has become the most dominant energy storage device in the market. $\mathrm{LiCoO}_{2}(\mathrm{LCO})$ has been the most investigated electrode material from the time of its earliest discovery by Goodenough et al. [13]. However, despite its successful commercialization, LCO suffers from several drawbacks, e.g., structural degradation and oxygen release at highly de-lithiated states $\left(\mathrm{Li}_{1-x} \mathrm{CoO}_{2}\right.$ where $\left.x>0.5\right)[10,14]$ and low specific capacity of $140 \mathrm{mAh} \mathrm{g}^{-1}$ (i.e., $\sim$ half of the theoretical capacity, $274 \mathrm{mAh} \mathrm{g}^{-1}$ ) [15]. Besides, cobalt (Co) is very expensive and toxic, which leads to an increase in the carbon footprint of the cathode active materials [16]. These practical challenges have been the stimulus behind the search for other alternative crystallographic systems. Lithium iron phosphate $\left(\mathrm{LiFePO}_{4}, \mathrm{LFP}\right)$ is another interesting cathode material of high structural and thermal stabilities (i.e., no oxygen release) due to the strong Fe-O covalent bonds and cycling stability; however, it operates at a lower voltage, thus reducing its power density when compared to LCO [17].

On the contrary, despite the high energy and power densities and relatively high operating voltage $\left(\sim 4.1 \mathrm{~V}\right.$ vs. $\left.\mathrm{Li} / \mathrm{Li}^{+}\right)$of high voltage spinel-like $\mathrm{Li}_{2} \mathrm{MnO}_{4}(\mathrm{LMO})$ cathode materials, they suffer from accelerated capacity fading during prolonged cycling, storage, and, at elevated temperatures, attributed to Mn dissolution [14].

Ni-rich layered cathodes have been materialized as next generation materials because of their relatively high discharge capacity (i.e., $180-230 \mathrm{mAh} \mathrm{g}^{-1}$ ), lower overall cost, and so forth in the search for high-performance devices. Recently, the research interest in Ni-rich cathodes has been exponentially augmented (Figure $1 \mathrm{a}, \mathrm{b}$ ), once again proving the huge attention that is given by the academia, governments and industries. However, Ni-rich cathode materials are beset with detrimental challenges, hindering their large-scale integration into the evolving xEVs market.

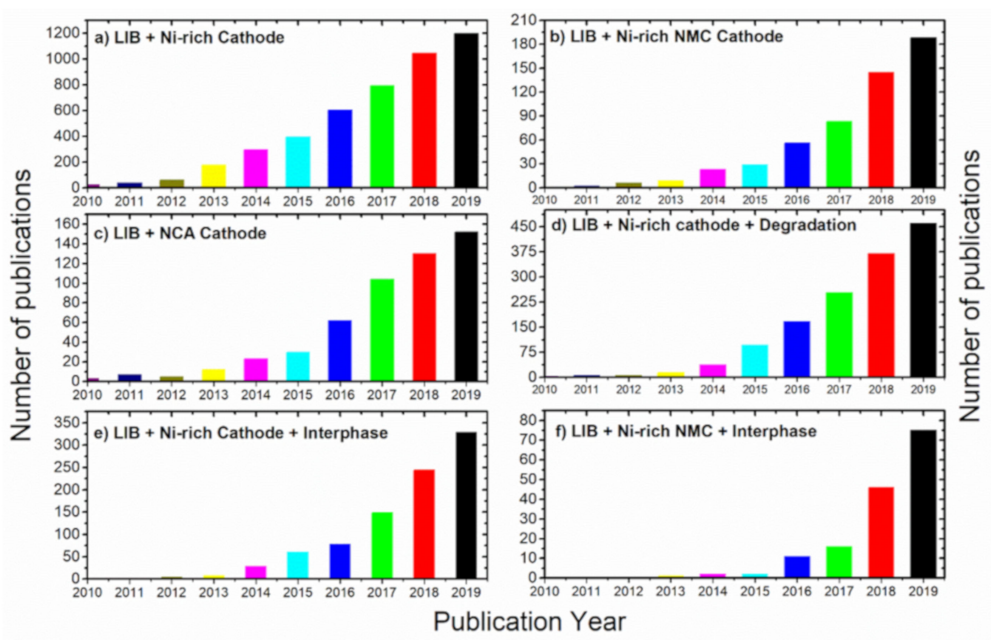

Figure 1. Overall research activity on Ni-rich cathode based lithium-ion batteries (LIBs) (Last updated 20th October 2019). The key search words used in Scopus are, "Lithium-ion battery", Lithium-ion battery + Nickel rich cathode" and "Lithium-ion battery + Nickel rich cathode + degradation or interphase". 
Among others, issues that are related to the Ni-rich cathode/electrolyte interphase (CEI) and complex degradation origins as well as routes have received significant attention (Figure 1c-f). Herein, we review the critical impediments for the large scale commercialization of Ni-rich cathode based LIBs and recent progress in the search of enabling mitigating strategies. For the sake of readers, the chemistry, major challenges enlisting the unstable CEI and degradation phenomena as well as proposed solutions and research directions are addressed in Sections 2-4, respectively. Finally, a conclusive remark shedding light on the future research directions is precisely presented.

\section{Chemistry of Ni-Rich Cathode Materials}

The fundamental features of Ni-rich cathodes, $\left(\mathrm{Li}\left[\mathrm{Ni}_{x} \mathrm{M}_{1-x}\right] \mathrm{O}_{2},(x \geq 0.6, \mathrm{M}=\right.$ transition metal), are predominantly dictated by the chemistry, i.e., elemental composition, namely nickel (Ni), cobalt (Co), manganese (Mn), aluminum (Al), and any other incorporated dopants (if exist) [18]. Transition metal cations and their chemistries play a major role in the aging and degradation processes in layered cathode based LIBs. The composition and oxidation state of each transition metal cation contribute to the electrochemical performance, thermal stability, overall material cost, toxicity, etc. of the Ni-rich cathodes. In general, nickel $(\mathrm{Ni})$ serves as a source of valence states of $+2\left(\mathrm{Ni}^{2+}\right)$ and $+3\left(\mathrm{Ni}^{3+}\right)$ in Ni-rich electrodes. However, at certain conditions, such as at a very low lithiation state, the high oxidative $+4\left(\mathrm{Ni}^{4+}\right)$, whose compounds are soluble in the electrolyte, is observed [19]. Unlike LCO, $\mathrm{LiNiO}_{2}$ (LNO) is more challenging due to the instability resulting in the spontaneous reduction of $\mathrm{Ni}^{3+}$ to $\mathrm{Ni}^{2+}$, and thereby its migration within the Li layers. The substitution of stable $\mathrm{Co}^{3+}$ for the unstable $\mathrm{Ni}^{3+}$ minimizes the formation of $\mathrm{Ni}^{2+}$ species, favoring the development of $\mathrm{Li}(\mathrm{Ni}, \mathrm{Co})$ $\mathrm{O}_{2}$ solid solution, i.e., $\mathrm{LiNi}_{1-y} \mathrm{Co}_{y} \mathrm{O}_{2}$ to prevent such undesired transformation. Such Co-doping improves the structural integrity and promotes better stability in the charged state. Interestingly, the substitution of $\mathrm{Ni}$ with electrochemically inactive $\mathrm{Al}$ appeared to be interesting, which further increases the electrode thermal stability due to the stronger Al-O linkage when compared to Ni-O bonding. However, the improvement in the cathode electrode stability at high voltage and cycling life decreases, owing to its electrochemical inertness. Later, dual substitution of $\mathrm{Co}$ and $\mathrm{Al}$, aiming at harvesting the synergistic benefits of both elements, pursued the development of $\mathrm{Li}\left[\mathrm{Ni}_{1-x-y} \mathrm{Co}_{x} \mathrm{Al}_{\mathrm{y}}\right] \mathrm{O}_{2}$, coined as NCA [20]. Amid several NCA varieties, $\mathrm{Li}\left[\mathrm{Ni}_{0.80} \mathrm{Co}_{0.15} \mathrm{Al}_{0 \cdot 05} \mathrm{O}_{2}\right.$ and $\mathrm{Li}\left[\mathrm{Ni}_{0.81} \mathrm{Co}_{0.10} \mathrm{Al}_{0 \cdot 09}\right] \mathrm{O}_{2}$ have been ascribed as the most promising versions, which satisfy safety criteria without compromising the energy density, power or cost benefits of Ni-based cathodes. Another possibility to substitute $\mathrm{Ni}$ is with $\mathrm{Mn}$, hoping to enhance the operating voltage while keeping the structural integrity and lowering the cost and toxicity of the resulting material. Doping Ni with both Co and Mn leads to the development of very exciting crystallographic systems, called NMC materials, $\mathrm{Li}\left[\mathrm{Ni}_{x} \mathrm{Co}_{y} \mathrm{Mn}_{z}\right] \mathrm{O}_{2}$ $(x+y+z=1)$, with specific variants, such as $x: y: z=1: 1: 1$ (NMC111), 5:3:2 (NMC532), 6:2:2 (NMC622), 8:1:1 (NMC811), 85:7.5:7.5 (NMC857575), and so forth, where the numbers denote the ratio of $\mathrm{Ni}, \mathrm{Co}$, and $\mathrm{Mn}$ on a mole fraction basis. ${ }^{6}$ The role of each transition metal in NMC is detailed in Figure 2a,b, clearly depicting their splendid effect on the discharge capacity, capacity retention, and thermal stability. Increasing $\mathrm{Ni}$ content clearly depicts an increase in the discharge capacity, but at the expense of thermal stability and capacity retention. 
a)

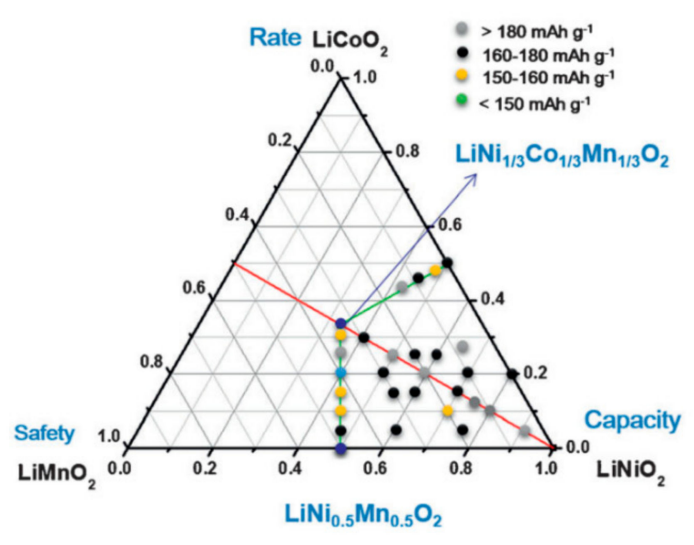

b)

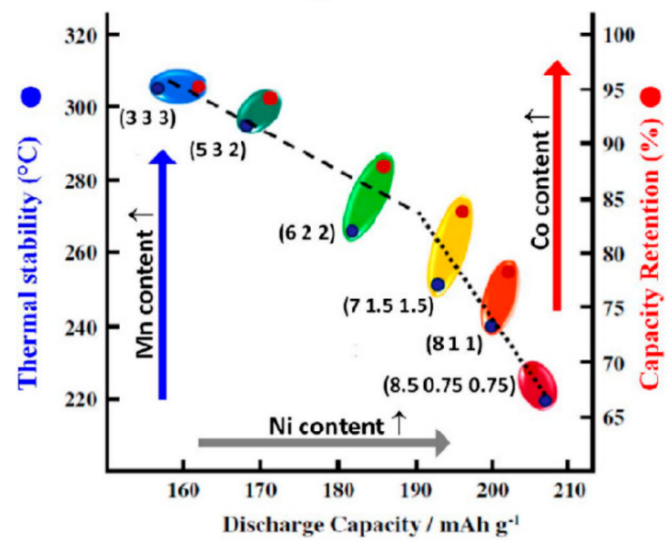

Figure 2. (a) Compositional phase diagrams of lithium stoichiometric-layered transition-metal oxide: $\mathrm{LiCoO}_{2}-\mathrm{LiNiO}_{2}-\mathrm{LiMnO}_{2}$. The positions indicated by dots represent the described $\mathrm{LiNi}_{1-x-y} \mathrm{Co}_{x} \mathrm{Mn}_{y} \mathrm{O}_{2}$, reproduced from Ref. [21] with permission, Copyright 2015, John Wiley and Sons; (b) Sketch on the effect of transition metals on discharge capacity (black), thermal stability (blue) and capacity retention (red) of $\mathrm{Li}\left[\mathrm{Ni}_{\mathrm{x}} \mathrm{Co}_{\mathrm{y}} \mathrm{Mn}_{\mathrm{z}}\right] \mathrm{O}_{2}$ compounds with number in brackets corresponding to the composition (Ni, Mn, Co). The positive effect of $\mathrm{Ni}$ on capacity, Mn on thermal stability and Co on capacity retention and rate performances is underlined. Reproduced with permission from Ref. [22], Copyright 2015, Electrochemical Society.

\section{Challenges and Origins Associated with Ni-Rich Cathode Materials}

Despite the fact that Ni-rich cathode materials have reaped enormous courtesy as next generation cathode materials, their commercialization is still limited to lower $\mathrm{Ni}$ content, $\mathrm{Ni} \leq 60 \%$ for NMC and $\mathrm{Ni}=80 \%$ (by molar fraction) for NCA. Low Ni content-NMC/LMO blended cathode in Chevrolet Volt (PHEV), BMWi3 (BEV), as well as Nissan Leaf (BEV), pure NMC in Daimler Smart EV (BEV) and NCA in Daimler S class hybrid (HEV), Tesla Model S (BEV), and the BMW active Hybrid7 (HEV) have been commercialized for applications in the electro mobility [23,24]. However, these success stories cannot meet the harsh requirements of future generation batteries in terms of energy density $\left(>400 \mathrm{Wh} \mathrm{kg}^{-1}\right.$,

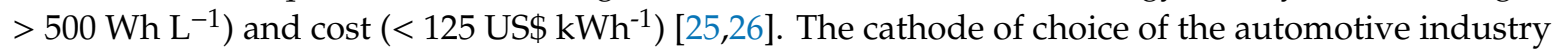
for the "near-future" xEVs versions is directed to Ni-rich NMC and NCA, combined with access to high voltage operations [27]. However, the practical application with Ni content over $60 \%$ is severely hindered due to the presence of various inter-linked challenges. Ni-rich layered oxides generally suffer from two major problems, i.e., performance degradation and safety hazards, especially during storage or operation near the fully delithiated state and/or at high temperature. Generally, the origins for the performance degradation are linked to residual lithium compounds (RLC), Ni/Li cationic mixing (disordering), oxygen evolution reaction (OER), irreversible phase transition, transition metal dissolution, micro cracking of secondary particle structure, and so forth. Thus, an in-depth evaluation of the existing obstacles and accompanying origins of NMC and NCA cathode materials in general and those Ni-rich one in particular are presented in the following sub-sections.

\subsection{Lithium Residual Compounds from Synthesis}

There exist various synthesis methods that lead to the production of Ni-rich cathode materials, such as atmospheric plasma spray pyrolysis [28], pulse combustion [29], sputter deposition [30], and co-precipitation [31], to name a few. The latter is the most popular synthesis route, which firstly involves the formation of precursor in a continuous stirring tank reactor (CSTR) by co-precipitation. The divalent transition metal ions are then introduced into the CSTR under inert atmosphere, e.g., as sulfate salts. Furthermore, sodium hydroxide and ammonium hydroxide are added to control the $\mathrm{pH}$-value and as chelating agent, respectively. The stoichiometry of the transition metal hydroxide 
precursor determines the stoichiometry of the final product in terms of the Ni: Mn: Co ratio. Afterwards, the precursor is dried and mixed with a stoichiometric equivalent amount of $\mathrm{Li}_{2} \mathrm{CO}_{3}$ or $\mathrm{LiOH}$ by ball milling and, finally, sintered in air. During the synthesis route, a large number of parameters can affect the final product, such as $\mathrm{pH}$-value, amount of ammonia, stirring speed, calcination temperature, and so forth [32].

For example, NMC111 sub-micron particles were obtained at an elevated pH-value, low ammonia content, and relatively low calcination temperature [33]. While the nucleation and its growth rate are $\mathrm{pH}$ dependent, the agglomeration of primary to secondary particles depends on the amount of ammonia that is added during the synthesis process. In short, the synthesis history plays a huge role in the degradation phenomenon of Ni-rich cathode materials. For instance, the synthesis conditions (e.g., nature and concentration of precursors and other reagents, sintering and co-precipitation temperatures, $\mathrm{pH}$ value, stirring speed, etc.) and synthesis protocols profoundly affect the particle size, crystallinity, morphology, structural stability, and cation ordering. This eventually plays a decisive role in the degradation process (e.g., by creating active surface driven side reactions and others) and, thus, in the electrochemical performance of the final products. Tian et al. [34] evidenced liquid electrolyte penetration limits, which are consequences of the morphological appearance of the NMC particles, leading to heterogeneous state-of-charge $(\mathrm{SoC})$ distribution within the cathode active material particles. This, in turn, leads to an inhomogeneous aging within the particles.

Unreacted lithium ingredients can often remain on the surfaces of the active materials, ostensibly in the oxide form of $\mathrm{Li}_{2} \mathrm{O}$, because an excessive amount of lithium is compulsory to produce decidedly crystalline Ni-rich layered materials. The presence of these residual lithium compounds (RLCs), which are inescapably available in Ni-rich cathodes with their amount increasing with the Ni content (i.e., $\sim 6 \times 10^{3}$ to $25 \times 10^{3}$ ppm for $\mathrm{Ni} \geq 60 \%$ ), are highly detrimental. RLCs can be originated via two routes: (i) excess amount of $\mathrm{LiOH}$ introduced during the synthesis for recompensing the loss of $\mathrm{Li}_{2} \mathrm{O}$, by sublimation, and subduing the $\mathrm{Ni} / \mathrm{Li}$ mixing [35], and (ii) via reactions with $\mathrm{H}_{2} \mathrm{O}\left(\mathrm{LiNiO}_{2}+x \mathrm{H}_{2} \mathrm{O}\right.$ $\left.\rightarrow \mathrm{Li}_{1-x} \mathrm{H}_{x} \mathrm{NiO}_{2}+x \mathrm{LiOH}\right)$ and/or $\mathrm{CO}_{2}\left(2 \mathrm{LiNiO}_{2}+x \mathrm{H}_{2} \mathrm{O}+x \mathrm{CO}_{2} \rightarrow 2 \mathrm{Li}_{1-x} \mathrm{H}_{x} \mathrm{NiO}_{2}+x \mathrm{Li}_{2} \mathrm{CO}_{3}\right)$ in air during storage [35,36]. Moreover, RLCs compounds can cause the gelation of the slurry during electrode preparation that is associated with dehydrofluorination of polyvinylidene fluoride (PVDF) binder by $\mathrm{LiOH}\left[\left(\mathrm{CH}_{2}-\mathrm{CF}_{2}\right)_{n}+\mathrm{LiOH} \rightarrow(\mathrm{CH}=\mathrm{CF})_{n}+\mathrm{LiF}+\mathrm{H}_{2} \mathrm{O}\right.$ ] [37]. Moreover, the strong alkalinity nature of RLCs can catalyze the transesterification and, thus, cascading degradation of carbonate based solvents, resulting in battery swelling and/or gassing [38]. The electrochemical oxidation of $\mathrm{Li}_{2} \mathrm{CO}_{3}$ at a potential $>4.3 \mathrm{~V}$ vs. $\mathrm{Li} / \mathrm{Li}^{+}$also results in the formation of oxygen and $\mathrm{CO}_{2}\left(2 \mathrm{Li}_{2} \mathrm{CO}_{3} \rightarrow 4 \mathrm{Li}^{+}+\right.$ $\left.4 \mathrm{e}^{-}+\mathrm{O}_{2}+2 \mathrm{CO}_{2}\right)$, eventually causing battery swelling [39-41]. The potential reaction of $\mathrm{Li}_{2} \mathrm{CO}_{3}$ with protic species (e.g., $\mathrm{Li}_{2} \mathrm{CO}_{3}+2 \mathrm{H}^{+} \rightarrow \mathrm{CO}_{2}+\mathrm{H}_{2} \mathrm{O}+2 \mathrm{Li}^{+}$), which can inevitably be generated during cell cycling, can also lead to severe gassing. In general, RLCs in the form of mixtures of $\mathrm{Li}_{2} \mathrm{O}, \mathrm{LiOH}$, and $\mathrm{Li}_{2} \mathrm{CO}_{3}$ play a key role in the degradation of Ni-rich cathode based LIBs and their ratio varies with storage conditions, such as humidity level in the air, time, etc. Thus, the amount of RLCs should kept lower than 3000 ppm for an acceptable level, owing to their detrimental effect [20]. Besides to employing tailored synthesis protocols, surface modification, for instance, with $\mathrm{H}_{3} \mathrm{PO}_{4}$ to produce a $\mathrm{Li}_{3} \mathrm{PO}_{4}$ coating layer upon heating and thus trapping three lithium atoms and thereby decreasing the impurities, has been proved to be an effective strategy [42]. The resulted $\mathrm{Li}_{3} \mathrm{PO}_{4}$ later can trap not only $\mathrm{HF}$, but also $\mathrm{H}_{2} \mathrm{O}$ as $\mathrm{Li}_{3} \mathrm{PO}_{4}+\mathrm{H}_{2} \mathrm{O} \rightarrow \mathrm{Li}_{x} \mathrm{H}_{y} \mathrm{PO}_{4}$ (or $\left.\mathrm{PO}_{x} \mathrm{H}_{y}\right)+\mathrm{Li}_{2} \mathrm{O}$, thus improving the electrochemical performances. Figure 3 depicts the surface change of Ni-rich cathode materials and accompanying changes in the cathode-electrolyte interphases [43]. 
a)
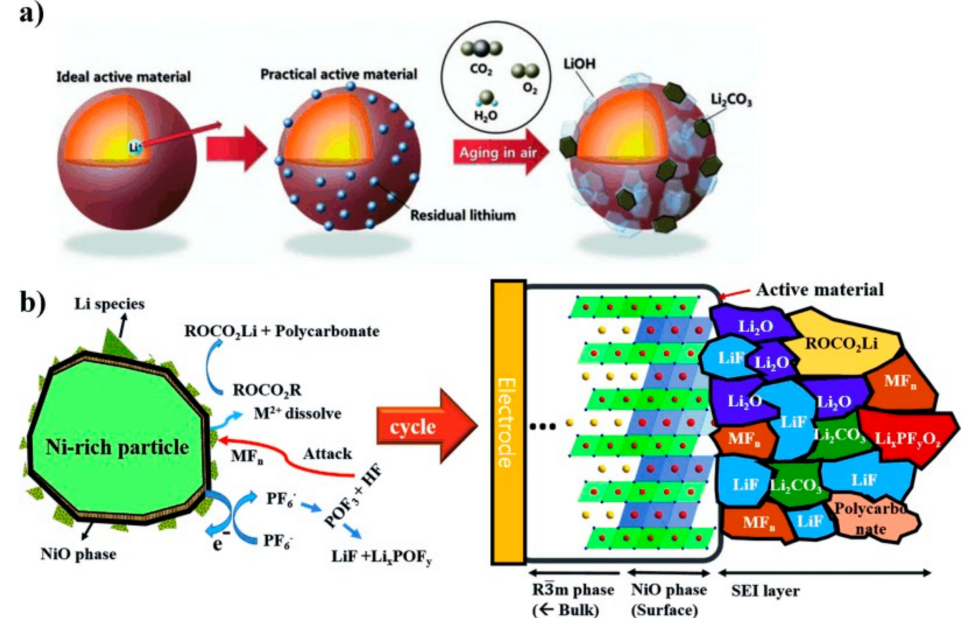

Figure 3. Illustration of the surface changes of Ni-rich cathode materials. (a) Surface change of Ni-rich materials after exposure in air, taken from Ref 37. (b) The microstructure and composition of the cathode-electrolyte interface at the surface of Ni-rich cathode materials, Reproduced from Ref. [20] with permission, Copyright 2015, John Wiley and Sons.

\section{2. $M /$ Li Cationic Mixing}

Among the principal cations in Ni-rich cathode materials, i.e., $\mathrm{Ni}^{2+}, \mathrm{Co}^{2+}$, and $\mathrm{Mn}^{2+}, \mathrm{Ni}^{2+}$ ions have the strongest propensity to mix with $\mathrm{Li}^{+}$ions (Figure 4), which results in the reduction of both capacity and Li mobility (thus conductivity) and at the same time transforming the layered over spinel crystal to NiO-like rock salt phase, both during preparation and application [43-46]. The mixing tendency is assumed to be favored from the similarity in the ionic radius of $\mathrm{Ni}^{2+}(0.69 \AA)$ and $\mathrm{Li}^{+}$ $(0.76 \AA)[47,48]$. It is noteworthy to mention that the $\mathrm{Ni}^{2+} / \mathrm{Li}^{+}$mixing occurs not only during the synthesis process, but also over the whole life of the battery. Its degree increases with increasing the $\mathrm{Ni}$ content, ratio of $\mathrm{Ni}^{2+}$ to $\mathrm{Ni}^{3+}$, state-of-charge (SoC), and temperature. Instead, Doeff and co-workers proposed a super-exchange mechanism for $\mathrm{Ni}$-rich $\mathrm{NMC}$ materials, where $\mathrm{Ni}^{3+}$ has priority to exchange with $\mathrm{Li}^{+}$[49]. A change in the valance state of $\mathrm{Ni}$ ion $\left(\mathrm{Ni}^{3+} \rightarrow \mathrm{Ni}^{2+}\right)$ occurs in combination with oxidation of the nearest $\mathrm{Co}^{3+}$ ion $\left(\mathrm{Co}^{3+} \rightarrow \mathrm{Co}^{4+}\right)$ for charge compensation, where oxygen ion has a charge carrier role.

a)

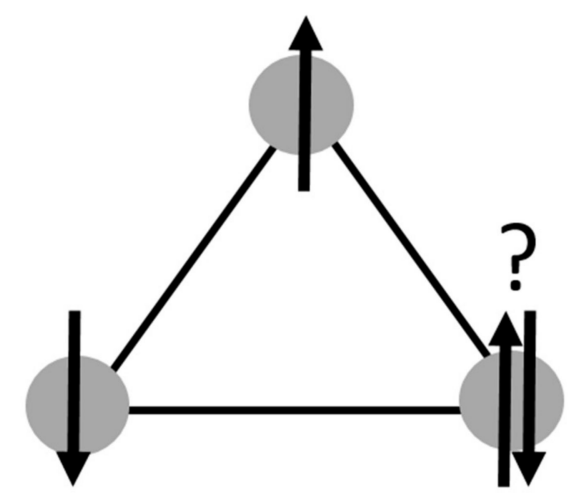

b)

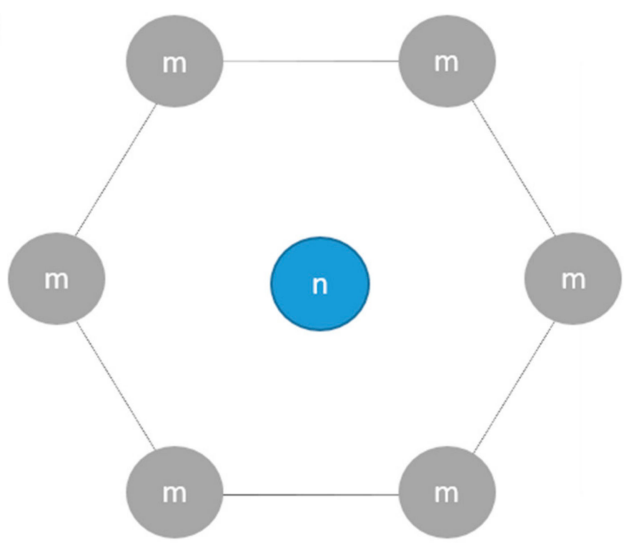

Figure 4. (a) Illustration of geometrical frustration where three ions with magnetic moments are arranged in trigonal planar, the sum of all moments cannot equal zero. (b) Rearrangement of ions within NMC to release geometric frustration, ions: m (grey) with magnetic moment, i.e., manganese and nickel form a hexagon with a non-magnetic, ion $\mathrm{n}$ (blue), i.e., cobalt or lithium, in its center. 
Koyama et al. [50] recently reported that cation mixing is a result of frustration (Figure 4a). In the TM layer of $\mathrm{NMC}, \mathrm{Ni}, \mathrm{Co}$, and $\mathrm{Mn}$ are arranged in trigonal planar. Hence, there is a potential for magnetic frustration, since the minimization of interaction energy of all nearest-neighbor spins is impossible. The frustration is released by a rearrangement of the TM elements from triangular coordination towards a hexagonal one, where $\mathrm{Co}$ is at the center of a hexagon of $\mathrm{Ni}$ and $\mathrm{Mn}$, in the case of NMC111 with a high amount of nonmagnetic $\mathrm{Co}^{3+}$ (Figure $4 \mathrm{~b}$ ). This implies that lowering the Co content (i.e., increasing $\mathrm{Ni}$ ) favors cationic mixing, which infers that cation-mixing leads to a thermodynamically preferred state of energy.

One of the possibilities for identifying and quantifying cation mixing is the utilization of X-ray diffraction (XRD), i.e., from the dependency of the ratio of the intensities of the (003) and (104) peaks on the amount of antisite $\mathrm{Ni}$ and Li. Patterns that were calculated using the WinPlotr tool of the FullProf Suite [50] show that, in low cation mixing (Figure 5a), the ratio of the peaks is 1.2, however, as the amount of cation mixing increases, the ratio $\mathrm{I}_{003} / \mathrm{I}_{104}$ is decreased (Figure $5 b$ ).

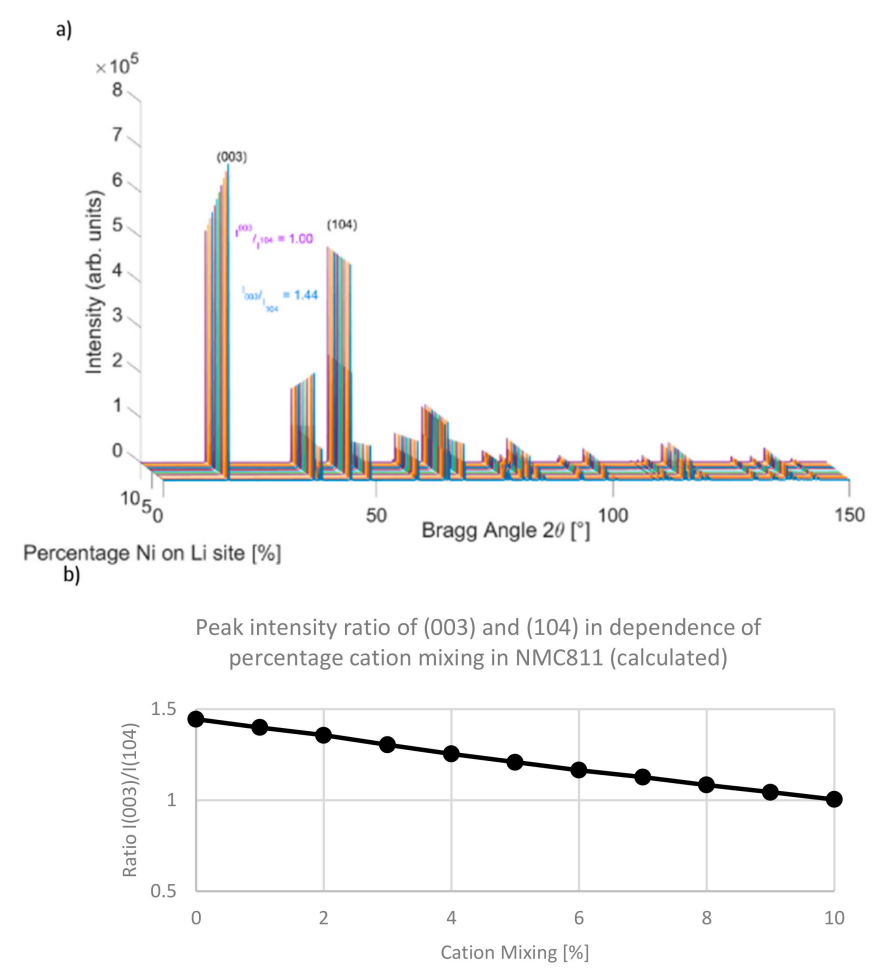

Figure 5. (a) Calculated X-ray diffraction (XRD) plot of NMC811 between $2 \theta=0 \ldots 150^{\circ}$ with indexed peaks (003) and (104) in case of cation mixing $0 \% \ldots 10 \%$, with an intensity ratio of (003) and (104) peak of 1.44 in case of no cation mixing and a ratio of 1 in case of $10 \%$ antisite Nickel. (b) Calculated on dependency between peak intensity ratio of (003) to (104) and percentage cation mixing in the case of NMC811. Pattern calculation was carried out with WinPlotr tool of FullProf Suite.

Strategies for reducing cation mixing includes: (i) over-lithiation: where the ratio between the lithium species and the transition metal hydroxide precursor is higher than one. The positive influence of this strategy is explainable with the additional insertion of lithium into the TM layer and thereby reducing the frustration. However, the introduction of excess lithium species also lead to a greater amount of Li residues after calcination, which results with issues during electrode fabrication, storage, and cycling, (ii) increasing the partial pressure of oxygen deriving the reaction, $\left[\mathrm{Li}_{x} \mathrm{NiO}_{2}\right.$ (layered) $\rightarrow$ $3 \mathrm{NiO}$ (rock salt) $+3 x / 2 \mathrm{Li}_{2} \mathrm{O}+6-3 x / 4 \mathrm{O}_{2}$ ], towards the layered oxide, (iii) increasing the thermodynamic stability of the layered oxides, (iv) lowering Ni content and limiting SoC, by decreasing the lower and upper cut off voltages, but this is at the expense of the cell capacity and materials cost, (v) cation and/or anion doping, and (vi) surface coating and so forth. 


\subsection{Safety of Ni-Rich Cathodes}

The commercialization of Ni-rich cathode materials austerely needs the full-scale appraisal of their safety-induced risks. It has been proven that the thermal stability of NMC decreases with increasing its $\mathrm{Ni}$ content, i.e., against increasing capacity and decreasing material cost [51]. From Figure 6a, it is clear that increasing the $\mathrm{Ni}$ content results in decreasing the onset decomposition temperature and increasing the strength of the exothermic peak (i.e., degree of heat release as can be evaluated by the enthalpy, $\Delta \mathrm{H}$ ) as well as pressure. This is attributed to the lower binding energy of $\mathrm{Ni}^{3+}-\mathrm{O}$ bond and, thus, oxygen get released during calcination from the layered lithium transition metal oxide structure, which leads towards shifting in the ratio between $\mathrm{Ni}^{2+}$ and $\mathrm{Ni}^{3+}$ and introduction of oxygen defects into the lattice favoring cation mixing. Figure $6 b, c$ give the decomposition of the predominant electrolyte solvent (ethylene carbonate, EC) and liability towards gas evolution of alkyl carbonates in the presence of different electrode materials. It is attributed to the oxidation of the alkyl carbonates by the reactive oxygen that is released from the NMC lattice. The gassing kinetics of alkyl carbonate-based electrolytes on various cathode electrodes and conductive carbon (C65) shows that the onset potential for the evolution of gases (e.g., $\mathrm{CO}_{2}$ and $\mathrm{CO}$ ) heavily depends on the nature of the electrode materials and increases in the order of NMC811 < NMC111 NMC622 < C65 LNMO (Figure $6 b, c$ ) [52]. The difference in the gas evolution on NMC811 vs. the other NMC versions (i.e., NMC111 and NMC622) can be explained due to an increase in the portion of the highly reactive $\mathrm{Ni}^{3+} / \mathrm{Ni}^{4+}$ in the total amount of $\mathrm{Ni}$ with increasing the nickel content $(\geq 80 \%)$. This again reaffirms that a due care and in-depth investigation with respect to the thermal stability is needed for the commercialization of $\mathrm{Ni}$ rich (with $\mathrm{Ni} \geq 80 \%$ ) cathode materials.

a)

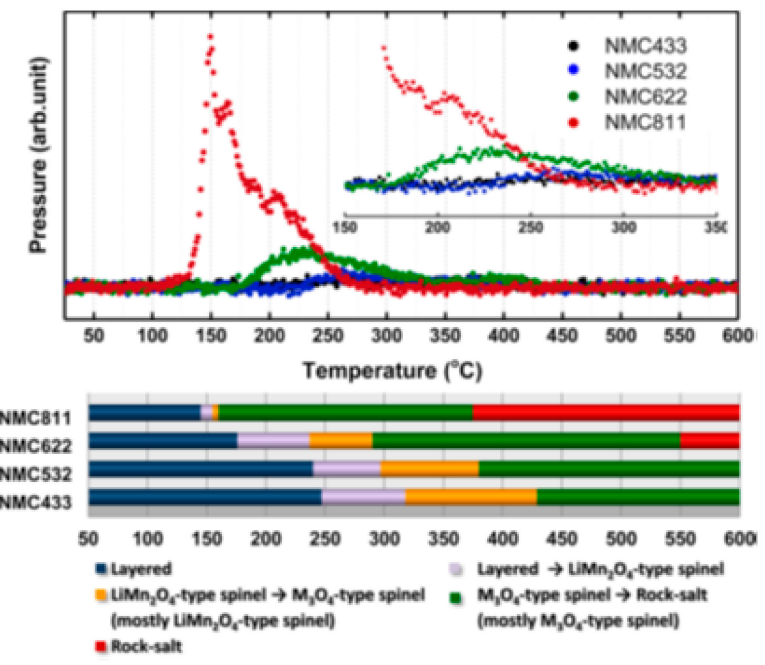

b)

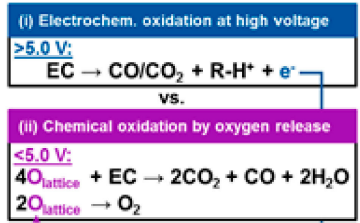

c)

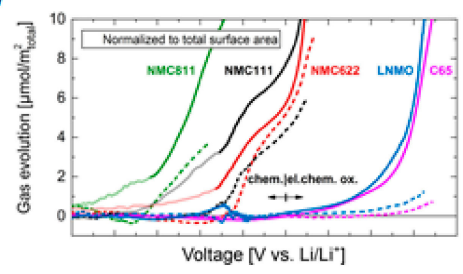

Figure 6. (a) Mass spectroscopy profiles for oxygen $\left(\mathrm{O}_{2}, \mathrm{~m} / \mathrm{z}=32\right)$ collected simultaneously during measurement of Time Resolved-X-Ray Difraction and the corresponding temperature region of the phase transitions for NMC samples (lower panel), reproduced from Ref [51] with permission, Copyright 2014, ACS, (b) gassing mechanisms in high-voltage LIBs, and (c) oxidative stability of carbonate electrolyte (1 $\mathrm{M} \mathrm{LiPF}_{6}$ in EC:EMC 3:7 wt/wt) on various electrode materials. (b) and (c) are reproduced from Ref. [52] with permission, Copyright 2017, ACS. 


\subsection{Effect of Electrode Manufacturing on Ni-Rich Cathode Ageing}

For practical applications, a slurry made of Ni-rich cathode powder material; carbon black and PVDF are mixed and subsequently dissolved in N-methyl-2-pyrrolidone (NMP) or N-ethyl-2 pyrrolidone (NEP) solvent. Afterwards, the resulting slurry is coated onto aluminum (Al) foil current collector, followed by a drying step via evaporating the dissolving solvent.

This process of slurry making suffers from several drawbacks, such as cost and toxicity, because NMP is hazardous, teratogenic and irritating, and PVDF is mutagenic and teratogenic [53]. Hence, alternative electrode processing approaches are of high importance to enhance the ecological and cost reduction benefits of LIBs. In this regard, water-based green binders, e.g., sodium carboxymethyl cellulose (Na-CMC), are of paramount importance. In terms of cost, NMP is more expensive $\left(1-3 \$ \mathrm{Kg}^{-1}\right)$ when compared to $\sim 0.015 \$ \mathrm{~L}^{-1}$ for water [53]. From polymeric binders perspective, the most commonly used aqueous-based binders, namely CMC $\left(-5 \$ \mathrm{Kg}^{-1}\right)$ and alginate $\left(\mathrm{Alg}, 8 \$ \mathrm{Kg}^{-1}\right)$, are cheaper than PVDF $\left(8-10 \$ \mathrm{Kg}^{-1}\right)$. Moreover, more energy is required for evaporation, even though the latent heat of evaporation of water is four times higher than the one for NMP, since NMP has a higher boiling point than water $\left(202^{\circ} \mathrm{C}\right.$ vs. $\left.100^{\circ} \mathrm{C}\right)$. Additionally, NMP solvent recovery is needed to avoid its dispersion into the atmosphere during drying (due to its higher toxicity) and a recovery system is also required to recycle the expensive solvent. However, despite the advantages of water as a solvent, water-based processing offers some challenges, such as the time-dependent dissolution of $\mathrm{Li}$, materials compatibility (e.g., side reaction of $\mathrm{Li}$ with water), dispersion, and formulation challenges, which call for careful consideration. For instance, the reaction of NMC with water not only leads to dissolution of Li, but also increases the $\mathrm{pH}$-value, which results in a more corrosive slurry against the $\mathrm{Al}$ current collector (i.e., leading to pitting corrosion). However, the formation of pitting can be lessened via controlling the $\mathrm{pH}$-value with phosphoric acid to keep it below and by coating the current collector with an electronic conductive layer, e.g., carbon [54].

To overcome both drawbacks, i.e., metal dissolution and pitting, surface coating (e.g., making use of metal oxides, fluorides, phosphates, etc., as detailed in the later sections) of the NMC particles seems suitable, as it disables the direct interaction between the electrolytes constitutes (i.e., solvent and salt anions) and NMC electrode particles. Other challenges that come along with water-based binders can be solved easily, e.g., by adding isopropyl alcohol to avoid cracking (Figure 7) in thick electrodes [55] and an adjusted drying route to avoid residual water in the electrode.

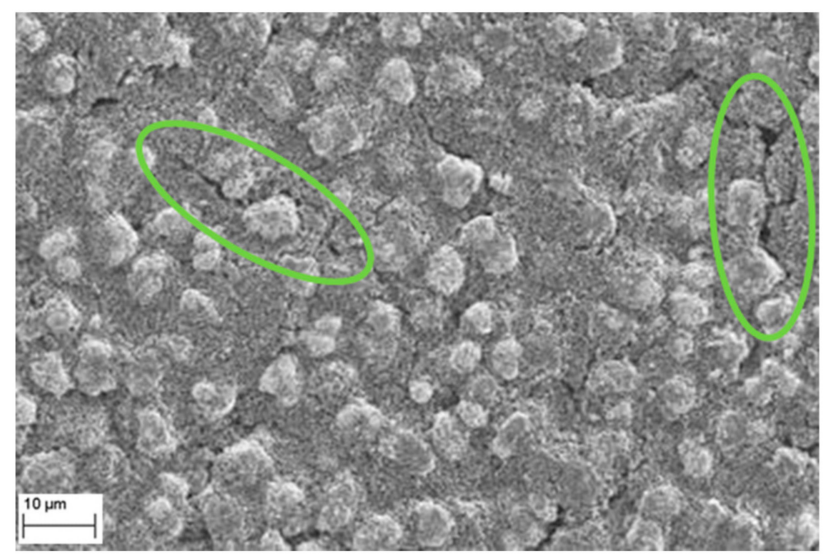

Figure 7. SEM image of cathode with cracks within binder structure but unimpaired cathode particles.

Another possibility for reducing the ecological footprint of LIB is the reusing and recycling of cell components, i.e.,finding second life application for cells. Since the end-of-life criteria for automotive cells is set to the state-of-health $(\mathrm{SoH})$ at $80 \%$, i.e., $80 \%$ of the initial capacity is remaining, they are still useable [56]. If a second life application is incapable, the recuperating of active material is possible in a destructive manner. After dissembling the LIB, one possibility would be the detachment 
of active material from the current collector by dissolving the binder [57]. The obtained particles may be unsuitable to be reused, as their active material is aged and binder residues diminish the electrochemical performance. Far more common is to leach out the transition metals and lithium. Hereby, in the case of the cathode, the Al current collector is dissolved in sodium hydroxide and NMC cathode in an acid. The obtained solution of transition metal ions and lithium ions can be treated and used for the synthesis of NMC [58-60]. Interestingly, Yang et al. [58] showed that the performance of NMC111 from recycled cathodes and pristine ones is comparable.

The importance of quality assurance to distinguish the sources of failure and ageing is highly recognized in the scientific community. Since binder degradation as a result of poor processing might lead to the detachment of active material and, thereby, capacity fade and increase of internal resistance, it can be confused with degradation phenomena of cathode active material, i.e., particle cracking and phase transformation. Hence, quality management might help to discriminate between the origins of both failures [60-62].

Defects can affect the performance of LIBs independent of the electrode-manufacturing route, and, in an extreme case, lead to failure of the whole cell [63]. Avoiding discard of electrodes and battery cells will lower fabrication costs, which makes LIB economical more attractive [64]. On the electrode's scale, Mohatny et al. $[65,66]$ employed two methods for operando quality management. The first method monitors the uniformity of the coating with the help of a laser caliper. The second one, IR thermography, is able to detect manufacturing defects, such as agglomerates, pinholes, metal particle contaminates, and so forth. Furthermore, they investigated the influence of these defects on the LIB performance, revealing that defect prevention is essential while considering lifetime and efficiency.

\subsection{Ni-Rich Cathode Ageing}

Ageing leads to capacity and power fading in LIBs and it results from degradation phenomena. On a material level, it is mainly attributed to the loss of lithium inventory and that of active materials either on the anode or cathode compartments $[67,68]$. Such changes can occur in calendrical, i.e., time dependent, or cyclic, i.e., dependent on the amount of transferred charges. Various studies have evidenced that particle cracking and phase transformation are the degradation mechanisms for many of the NMC compositions, including NMC111 [69], NMC442 [70], NMC532 [71], and NMC811 [72]. In general, Ni-rich NMC face serious degradation at higher upper cut-off voltage and elevated temperatures $[73,74]$. Figure 8 summarizes the main performance deterioration routes, enlisting electrolyte decomposition, $\mathrm{O}_{2}$ evolution, $\mathrm{Ni}^{2+}$ migration to the anode and precipitation, $\mathrm{CEI}$ dissolution, SEI contamination, and so forth in Ni-rich cathode materials [75].

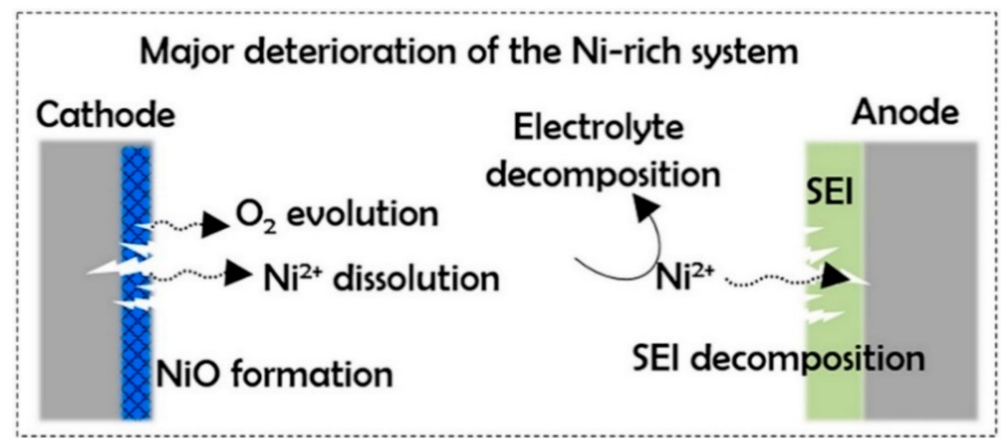

Figure 8. Schematic of the major deterioration of Ni-rich layered oxide system, adopted from Ref. [75] with permission, Copyright 2019, Elsevier.

\subsubsection{Micro Cracking of Secondary Particle Structure}

During charging, the voltage of the cathode electrodes is increased until a defined upper cut-off value leading to delithiated stage, i.e., extraction of $\mathrm{Li}$ ions from the layered structure $[73,76,77]$. 
The charge compensation is attributed to the transition metal, in particular, nickel ions and for higher voltage plateaus, cobalt [78]. XRD measurements revealed a volume change of the unit cell, which is attributed to changes of the lattice parameters $a$, and $c$. The shrinkage of parameter $a$ is correlated with the oxidation of the transition metals and linked to a decrease in the bond length between the transition metal ions. It is also reported that a stronger volume change of the unit cell occurs as the nickel content increases, which might be due to the higher amount of Jahn-Teller distortions induced by $\mathrm{Ni}^{3+}$ ions [79].

In the case of the lattice parameter $c$, representing the distance of the transition metal layers to each other, the situation is more complex. At first, the unit cell expands in $c$-direction as lithium is extracted due to an increased electrostatic repulsion between the oxygen atoms. As charging continues, a shrinkage of $c$ occurs. In NMC, there is a formation of a hybrid orbital consisting of transition metals with their characteristic d orbital and the oxygen p orbital. At higher degrees of delithiation, charge compensation is not solely provided by transition metal ions, but also by the hybrid orbitals, which leads to a charge transfer from the oxygen $2 \mathrm{p}$ orbital towards the partially filled nickel $\mathrm{e}_{\mathrm{g}}$ orbital. Consequently, the repulsion between oxygen atoms decreases and the parameter c shrinks due to the increase in the covalency between the metal and oxygen, and, in this case, the NMC becomes more reactive, being associated to the release of highly reactive oxygen (e.g., singlet or atomic oxygen) from the NMC lattice [80]. This ultimately leads to further accelerated degradation phenomena. At first, the volume change induces stress in the secondary particles, leading to cracks between the primary particles, i.e., intergranular cracking (Figure 9) [81,82]. As a consequence, capacity fading occurs, which is linked to the detachment of primary particles from the secondary particle matrix [83]. Here, the resistivity of detached particles increases drastically and, in an extreme case, it is present as inert phase [84]. A recent investigation of NCA particles by Besli et al. [85] proved such correlation and the authors showed that a local increase of impedance and the rearrangement of the diffusion paths is a result of intergranular cracking within the NCA particle [85]. Furthermore, there is a correlation between the particle size distribution of NMC particles and state of health, which indicates that degradation is a result of particle cracking $[57,86]$.
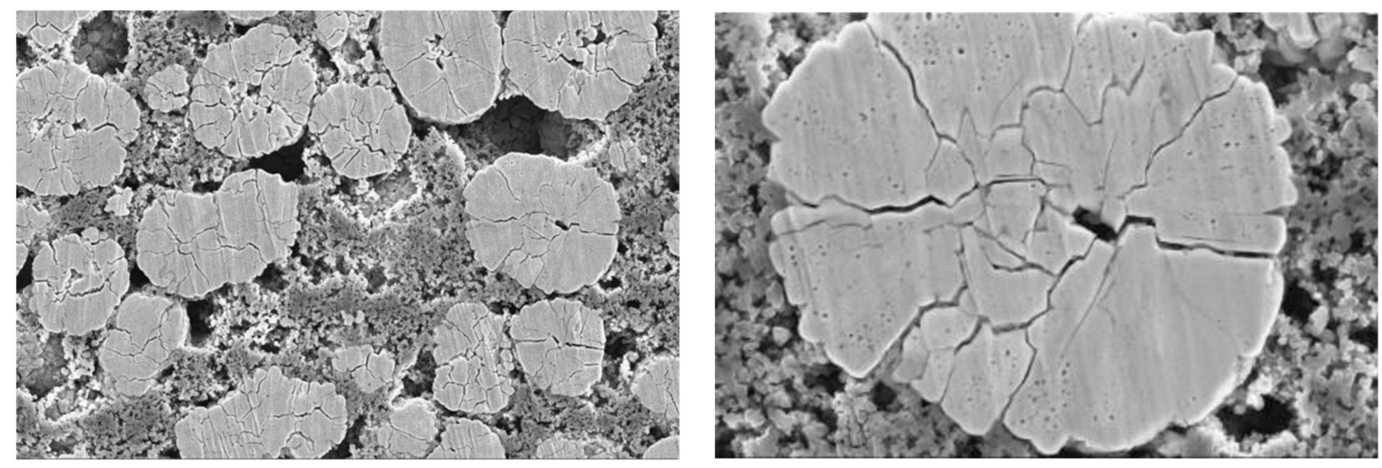

Figure 9. FIB-SEM secondary electron images of NMC111 after cycling under abusive conditions revealing crack evolution in secondary particles. (Left): magnification 30k, (Right): magnification 100k.

\subsubsection{Electrolyte Degradation and Interphasial Reactions}

The side reactions between the highly reactive delithiated cathode material and the electrolyte solution (i.e.,electrolyte degradation and gas generation) is one of the challenges that need to be overcome for the massive deployment of Ni-rich cathode based LIBs [87]. The evolution of a highly detrimental surface reaction layer (ca. cathode-electrolyte interphase, CEI), which is comparable to the solid-electrolyte interface on the anode side but less known and investigated, occurs on the cathode surface. The electrolyte degradation also leads to transition metal reduction, in particular $\mathrm{Ni}^{4+}$ for Ni-rich layered oxides, which are attributed to its low-lying lower upper molecular orbital (LUMO) [88-90]. 
In the course of Ni reduction, the energy barrier for phase transformation is lowered, which makes Ni-rich cathodes more prone to structural reconstruction that is associated with a phase transformation from R-3m over spinel structure Fd-3m to the Fm-3m rock-salt structure [77,91]. The formation of rock-salt structure is more probable at high upper cut-off voltages and high Ni contents [92].

Most importantly, each phase transformation is accompanied by a volumetric change in the lattice structure, which facilitates crack formation. This process increases the electroactive surface, favoring further electrolyte invasion [77,91]. The phase transformation is more likely to occur at the particle's surface, whereas the outer part of the particle is enriched with oxygen vacancies. Due to this, the expansion in the outer part is larger compared to the core one. The resulting mechanical stress initiates and propagates radial cracks, which ultimately lead to intragranular voids and the breakdown of the particles [83]. Moreover, the disproportionation of $\mathrm{Mn}$ ions $\left(2 \mathrm{Mn}^{3+} \rightarrow \mathrm{Mn}^{4+}+\mathrm{Mn}^{2+}\right)$ can possibly occur, which promotes further dissolution and formation of complexes between $\mathrm{Mn}^{2+}$ ions and carboxylate groups. Carboxylate groups result from electrolytic breakdown of the alkyl carbonate solvents, e.g., dimethyl carbonate or ethylene carbonate [93]. At this point, $\mathrm{Mn}^{2+}$ ions are capable of shuttling towards the anode and thereby contaminate it. Therefore, $\mathrm{Mn}^{2+}$ ions influence the SEI on the anode as they become deposited onto it. As a result, the loss of lithium inventory is accelerated, since a large amount of $\mathrm{Li}$ is trapped in the SEI in the presence of Mn-derived precipitated compounds, such as $\mathrm{MnF}_{2}[94,95]$. Thus, the electrocatalytic effect of manganese ions promotes electrolyte reduction, anode SEI growth, and, thereby, loss of lithium inventory.

\subsubsection{Layered-Spinel to Rock Salt Phase Transition}

Ni-rich cathode structural instability at the charged state is expressively connected to the oxygen gas evolution of the cell and $\mathrm{Ni}^{2+} / \mathrm{Li}^{+}$mixing. The highly unstable cathode at a charged state can easily degrade by exothermic and endothermic phase transitions and this transformation occurs via multiple steps and is highly anisotropic by nature. The unstable $\mathrm{Ni}^{4+}$ can be reduced to the stable $\mathrm{Ni}^{2+}$ via forming oxygen-containing species, such as $\mathrm{O}_{2}{ }^{-}, \mathrm{O}^{-}, \mathrm{O}_{2}{ }^{2-}$, and $\mathrm{O}_{2}$. A larger transformation layer in the lithium diffusion direction is visible than perpendicular to it (Figure 10a). During the structural distortion, firstly cation mixing is induced during cycling. Hereby, primarily nickel is capable of migrating towards unoccupied Li sites in the delithiated NMC, [96] resulting in the clogging of the $\mathrm{Li}^{+}$diffusion paths, leading to a decrease in the ionic conductivity. The result is a lithium containing transition metal spinel (Figure 10b), where lithium can be found on the tetrahedral site. As the degradation proceeds, the residual lithium is mainly extracted and replaced by cobalt, which is capable of migrating in a highly oxidized state, likewise nickel, on the tetrahedral site [96]. In the end, the rock-salt structure (Figure 10c), which has poor Li kinetics, thus leading to capacity fading and rise in the internal resistance, is formed $[35,97,98]$. The latter is well detectable with the help of electrochemical impedance spectroscopy (EIS), as described elsewhere [99].

$\mathrm{Mu}$ et al. [70,100] proposed that the phase transformation is locally induced by abnormal changes in the valence states of the transition metal ions through modeling and experimental evidences, i.e., reduction of transition metal ions without the intercalation of $\mathrm{Li}$. This could be linked to the interaction between electrolyte and delithiated NMC. As a result, the formation of nuclei of the new phase occurs. Each phase transformation is associated with the evolution of oxygen, owing to the hybridization of transition metal $d$ and oxygen p orbitals [101]. Wandt et al. indicated that the release of singlet oxygen ${ }^{1} \mathrm{O}_{2}$, i.e., reactive oxygen species and this oxygen release is dependent of the phase transformation and vice-versa [98]. Figure 11 depicts this phenomenon and the incremental capacity analysis (ICA) of pseudo-OCV curves of NMC111, NMC622, and NMC811, showing a shift of the high potential redox peak from approx. $4.65 \mathrm{~V}$ vs. Li for NMC111 to approx. 4.2 V vs. Li for NMC811. The peak is linked to an oxygen redox process during the charge and discharge process [35]. 
a)
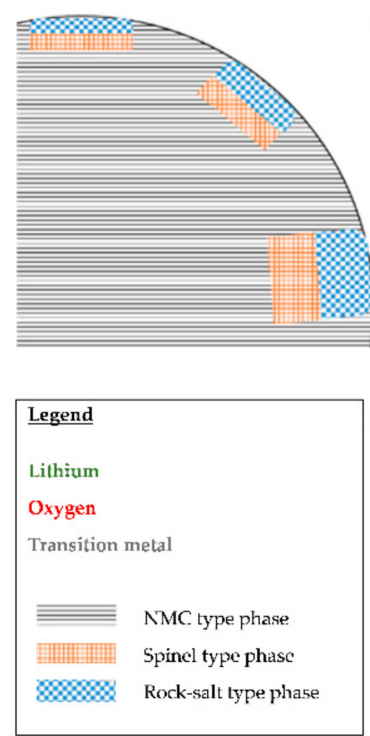
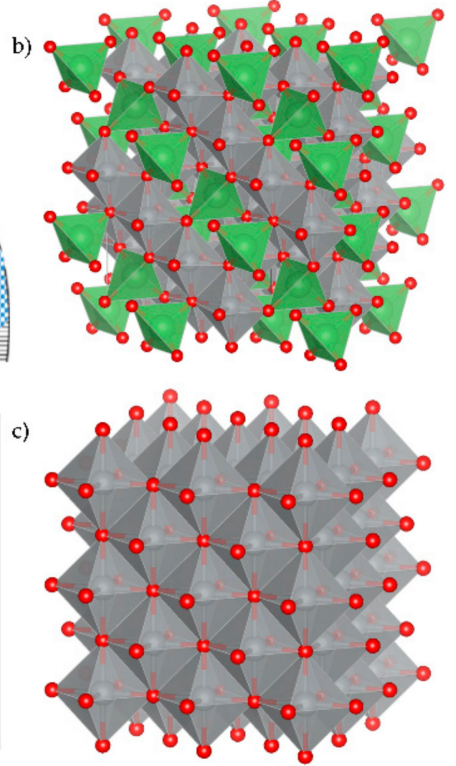

Figure 10. (a) Scheme of cross-sectional view in NMC particle revealing R-3m structure (layered) and exemplary regions of structural distortion, size of these sections is anisotropic, larger in direction of Li diffusion paths, orange section representing spinel type phase, blue section representing rock-salt type phase. (b) Fd-3m spinel type structure with $\mathrm{Li}$ (green) in tetrahedral coordination with oxygen (red) and transition metal (grey), mostly nickel in octahedral coordination representing first full phase transformation from layered structure towards distorted structures. (c) Fm-3m rock-salt structure with octahedral coordination of transition metal (grey), mostly nickel, with oxygen (red), structure is fully delithiated without Li ion conductivity. Structural models are plotted with VESTA.

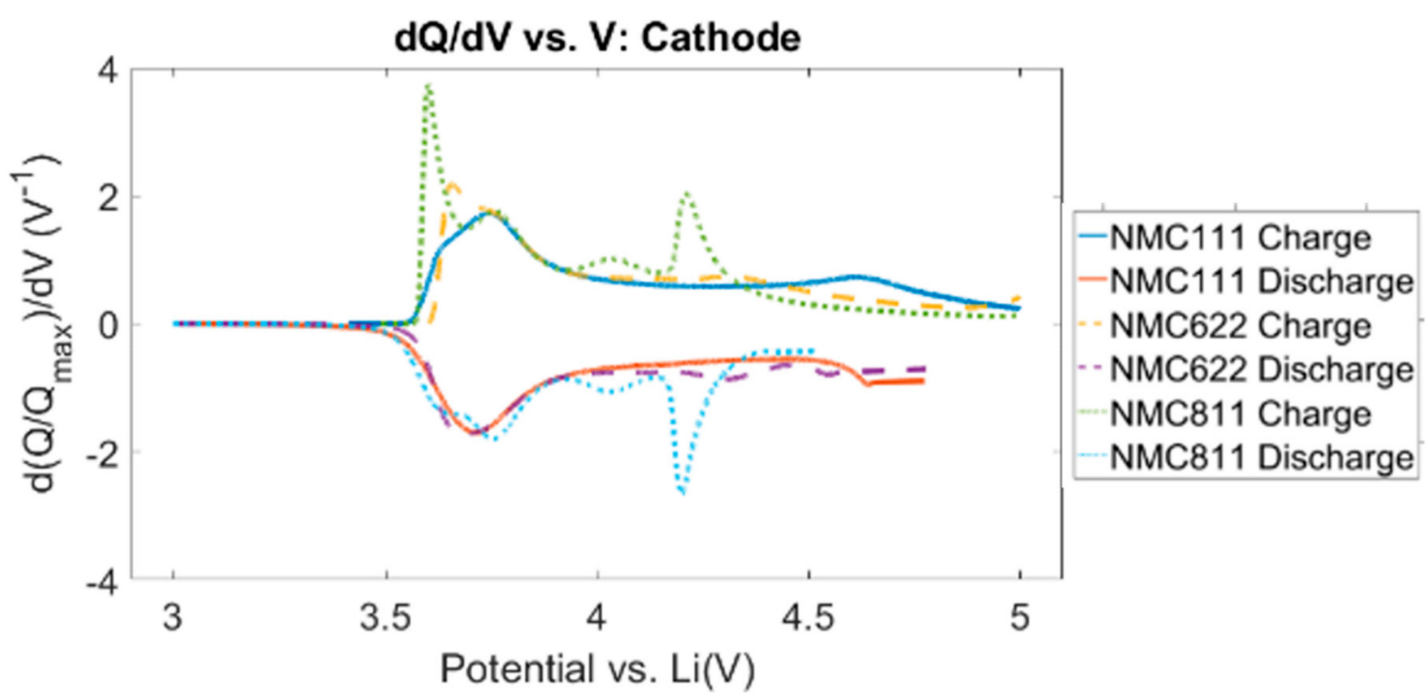

Figure 11. Incremental capacity analysis curve of NMC111 (solid line), NMC622 (dashed line) and NMC811 (dotted line) calculated from pseudo-OCV curves of the materials from C/25-charge and discharge. Highlighted peaks indicate redox peak with oxygen release characteristics.

The rate of phase transition is higher than oxygen transport and, thus, an accumulation of interstitial excess oxygen can occur to a certain degree of agglomeration due to phase transformation. During formation of the oxygen agglomerates, stress is evolved in the lattice and, finally, a crack is induced within the primary particle. Once the crack opened, oxygen is released, which might also result in additional electrolyte oxidation. 


\subsubsection{Transition Metal-Ion Dissolution and Anode-Cathode Dialogue}

Similar to phase transition, transition metal ion dissolution is the result of the combined effect of the M/Li mixing and OER. They both lead to the formation of low valence transition metal oxides assisted by the loss of oxygen, leading to cations whose salts are more soluble in liquid electrolytes than those composed of high valence transition metal ions are. The oxygen assisted solvent decomposition [(e.g., $\left.\left.\mathrm{C}_{3} \mathrm{H}_{4} \mathrm{O}_{3}(\mathrm{EC})+[\mathrm{O}] \rightarrow \mathrm{CO}_{2}+\mathrm{CO}+2 \mathrm{H}_{2} \mathrm{O}\right)\right]$ results in the formation of $\mathrm{H}_{2} \mathrm{O}$, which, in turn, hydrolyzes the salt $\left(\mathrm{LiPF}_{6} \leftrightarrow \mathrm{LiF}+\mathrm{PF}_{5}\right)$ in the electrolyte solution with the formation of $\mathrm{HF}\left(\mathrm{LiPF}_{6}+\right.$ $\mathrm{H}_{2} \mathrm{O} \rightarrow \mathrm{POF}_{3}+2 \mathrm{HF}+\mathrm{LiF} ; \mathrm{POF}_{3}+\mathrm{H}_{2} \mathrm{O} \rightarrow \mathrm{HF}+\mathrm{HPO}_{2} \mathrm{~F}_{2}$ ) [102]. This, in turn, attacks the metal oxide, which results in the formation of slightly more soluble $\mathrm{MF}_{2}$ salts and $\mathrm{H}_{2} \mathrm{O}$.

\section{Mitigating Strategies}

Many promising strategies have been proposed to date in response to the multifaceted challenges associated with Ni-rich cathode materials. Some of the major and representative approaches are briefly discussed henceforward.

\subsection{Tailoring Morphology of Ni-Rich Cathode Particles}

The morphology of the Ni-rich active materials greatly influences the electrochemical performance of Ni-rich cathode based LIB cells [103,104]. Thus, one of the approaches is then to tailor the electroactive surface, i.e., the plane across which $\mathrm{Li}$ is inserted or extracted. A large amount of surface area will increase the power density and seemingly deliver higher specific capacity during constant current discharge, which is distorted by the decrease of internal resistance. Nevertheless, a large surface area is also prone to accelerated electrolyte degeneration. Wang et al. [105] reported an improvement on the cycle performance by decreasing the surface area via adjusting the precursor concentration. Peralta et al. [33] synthesized non-agglomerated sub-micron flake-shape particles with a small ratio of electroactive surface at the edge planes, i.e., a small area for lithium insertion, following the approach to diminish the amount of active surface area. Thus, the surface reconstruction, which primarily occurs at the insertion planes, is impeded. A similar approach was carried out by Dahn group with the synthesis of single crystal NMC particles: NMC532 [106], and NMC622 [107], which were found to outperform their polycrystalline counterparts [108]. Single crystal morphologies are also found to be advantageous in avoiding intergranular cracking and, thus, improving the intercalation of $\mathrm{Li}$, which will otherwise be hindered by grain boundaries [109].

\subsection{Foreign-Ion Doping}

The incorporation of foreign-ions, which involve both cation and anion, is one of the simplest and most common strategy to augment the structural and thermal stabilities of Ni-rich layered oxides. In the case of cation doping, $\mathrm{Li}$ and transition metal sites are both considered. On the Li site, other alkali metals can be also introduced, i.e., besides to Li. The mechanism by which doping benefits the stabilization of Ni-rich cathodes is linked to: (i) integration of electrochemically inactive elements into the host structure, (ii) inhibition of undesired phase alterations, from layered over spinel to rock salt structure, and (iii) preferment of $\mathrm{Li}^{+}$mobility due to increased Li slab distance by the dopants. Electrochemically inactive ions, such as $\mathrm{Na}^{+}$[110], $\mathrm{Mg}^{2+}$ [111], $\mathrm{Al}^{3+}$ [112], and $\mathrm{Ti}^{4+}$ [113], etc., are among cation dopants that are recommended to boost the structural stability, reduce oxygen release and avoid cation mixing. The improvement is largely linked to the enlarged interlayer distance of $\mathrm{O}-\mathrm{Li}-\mathrm{O}$, impeding cation mixing and thereby enhancing structural stability.

Overlithiation, which was presented earlier as an approach for reducing initial cation mixing during synthesis, can be considered as cation doping of the transition metal layer [114]. In this case, the resulting structure is comparable to Li-rich $\mathrm{NMC}$, where $\mathrm{Li}$ is inserted into the transition metal layer of the layered R-3m structure. The beneficial features of this approach is the increase in capacity, albeit poor cycle life and fast capacity fading [115]. However, Wang et al. showed that there is an optimum 
limit for overlithiation of Ni-rich layered oxide cathodes, because, beyond this point, the performance of the material is diminished [116]. Another route of improving the material characteristic is the partial substitution of the transition metals. In this regard, Co came into focus due to its high toxicity and costs or Mn due to its electrochemical inactivity [117]. The substitution of Ni is insensible, since it provides most of the capacity to the battery cell. The choice of the dopant is attributed to the bond energy of the substituting element with oxygen, since high bonding energy is associated with improved structural stability [118]. In general, due to their electronic configuration, i.e., d-electrons, transition metals are capable of contributing to the capacity. For example, iron doped $\mathrm{LiNi}_{0.35} \mathrm{Mn}_{0.35} \mathrm{Co}_{0.27} \mathrm{Fe}_{0.03} \mathrm{O}_{2}$ deliver a higher capacity when compared to its iron free counterpart [119]. In case of doping with non-transition metal elements, the capacity of the cathode active material is lowered. Figure 12a shows significant improvement upon doping of Ni-rich NMC811 cathode with various cation dopants [120]. Among tested cations, tantalum $\left(\mathrm{Ta}^{5+}\right)$ is found to be the most effective dopant, improving the discharge capacity, capacity retention, and cycling stability at $45^{\circ} \mathrm{C}$.

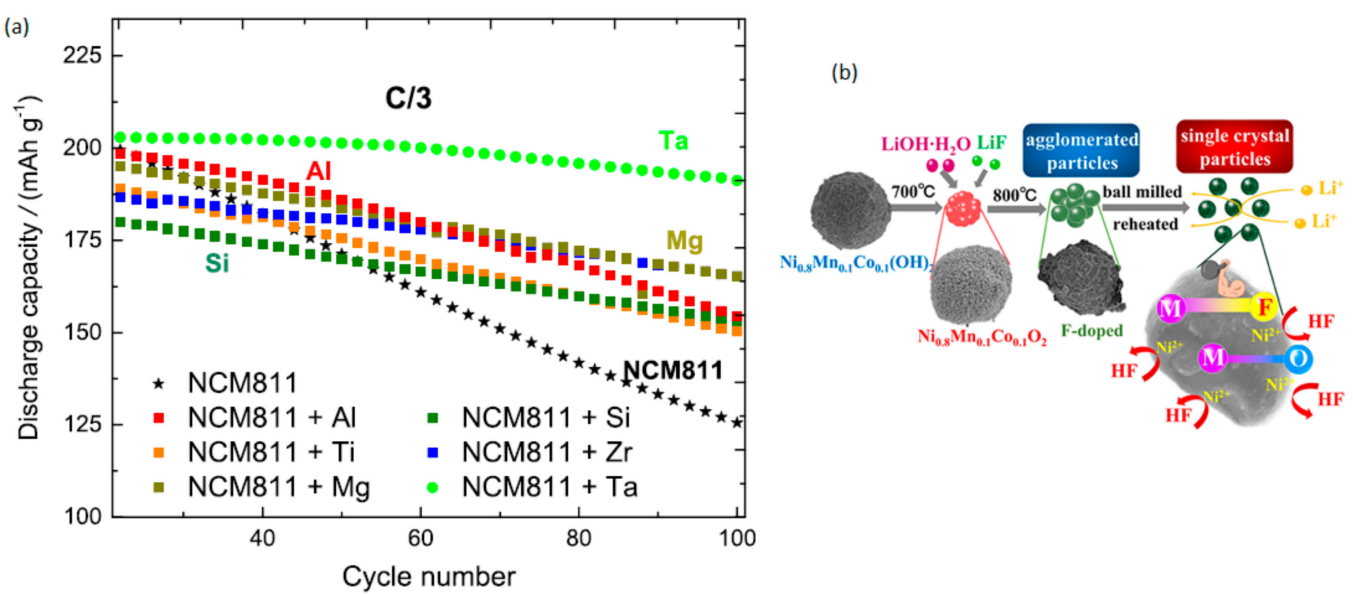

Figure 12. (a) Discharge capacities of NCM811 electrodes comprising undoped and cation doped active materials in coin cells at $45^{\circ} \mathrm{C}$, adapted from Ref. [120] with permission, copyright 2019, ACS (b) Fabrication of Fluorine doped NMC8111, reproduced from Ref. [121] with permission, Copyright 2019, Elsevier.

In addition, anion substitution is considered as one strategy, although it is predominantly adopted for Li-rich NMC materials. This involves the substitution of $\mathrm{O}^{2-}$ by other anions such as $\mathrm{F}^{-}, \mathrm{Cl}^{-}$, $\mathrm{S}^{2-}$ and so forth [19]. Among others, $\mathrm{F}^{-}$is predominantly used as anion dopant for strengthening the binding energy between the transition-metal cations and anions, and it is attributed to its more electronegativity (3.98) compared to $\mathrm{O}^{2-}$ (3.44). $\mathrm{O}^{2-}$ substitution by $\mathrm{F}^{-}$significantly improves the electrochemical properties of Ni-rich cathode materials, including capacity retention, rate capability, and thermal stability, and prevent the surface from attack by HF. Figure $12 \mathrm{~b}$ depicts the synthesis scheme of fluorine doped NMC cathode material [121].

\subsection{Core Shell and Gradient: Full Concentration Gradient}

In general, increasing the Ni content will increase the capacity and decrease the cost, but, at the same time, decreases the structural and thermal stabilities. In view of the latter, core-shell (Figure 13a) and full concentration gradient (Figure 13b), which are also more exemplified in Figure 13c, have been proposed as enabling solutions to address the degradation phenomenon in Ni-rich cathode materials [31,122]. Hereby, a core-shell should not be confused with surface coating. For the latter, a thin, non-isostructural film (in range of Angstrom or nanometer) is coated onto the Ni-rich cathode particles, whereas a thicker, isostructural, Li-ion conductive film is applied in the case of core-shell [19]. 


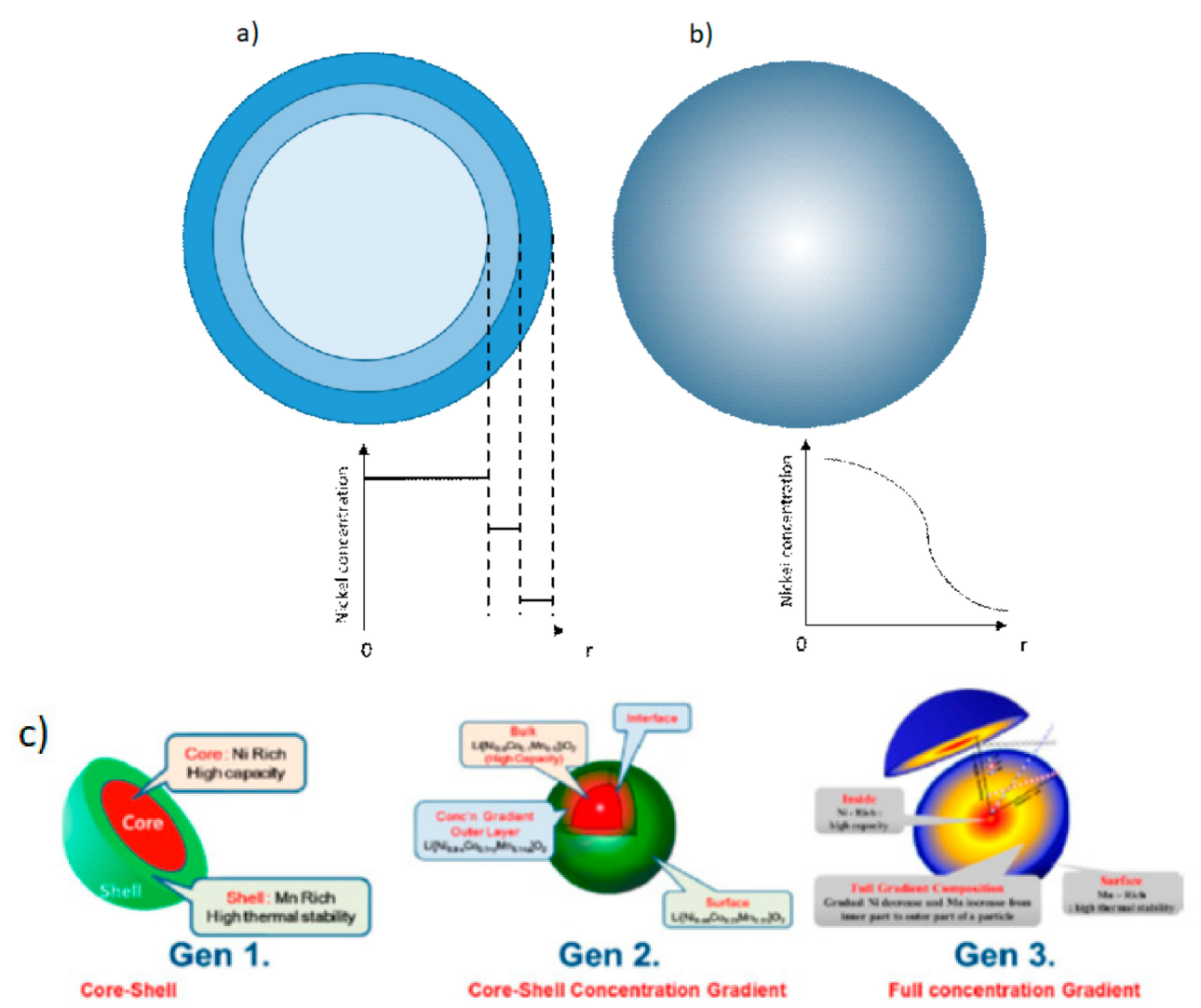

Figure 13. (a) Scheme of full concentration gradient through NMC particle, with Ni-rich core increasing capacity and Ni-poor shell with enhanced structural stability. (b) Scheme of (multilayer-) core-shell NMC particle, with Ni-rich core and Ni-poor shell(s). (c) (Left) Schematic drawings of a core-shell (Gen 1); (center) a Ni-rich core surrounded by a concentration gradient outer layer (Gen 2); and, (right) a FCG lithium transition metal oxide particle (Gen 3) with the nickel concentration decreasing from the center toward the outer layer and the concentration of manganese increasing accordingly. Reproduced from Ref. [122] with permission, Copyright2017, ACS.

The main target of this approach is to form a particle with a high $\mathrm{Ni}$ content in its core and a $\mathrm{Ni}$ depleted outer shell. In other words, a particle is synthesized with a structural stable shell and a high capacity core [123]. Depending on the smoothness of the concentration gradient, the modification is denoted as full concentration gradient, multilayer-core-shell, or core-shell (ordered by decreasing smoothness) [124]. Full concentration gradient (FCG) is an advanced form of core-shell structure and, accordingly, provides extra capacity, $200 \mathrm{mAh} \mathrm{g}^{-1}$ for full concentration gradient $\mathrm{LiNi}_{0.8} \mathrm{Co}_{0.1} \mathrm{Mn}_{0.1} \mathrm{O}_{2}$ vs $188 \mathrm{mAh} \mathrm{g}^{-1}$ for core-shell $\mathrm{LiNi}_{0.8} \mathrm{Co}_{0.1} \mathrm{Mn}_{0.1} \mathrm{O}_{2}$ at $4.3 \mathrm{~V}$ [125]. The FCG of Ni, Co, and $\mathrm{Mn}$ is stretched through the entire length of the particle with the compositions of $\mathrm{Ni}$ and $\mathrm{Co}$ linearly decreasing from the center and Mn smoothly increasing to the outer surface, leaving a Mn deficient interior.

When considering the synthesis route, there are differences between (multilayer-) core-shell and full concentration gradient Ni-rich cathode materials. Chen et al. [126] presented a co-precipitation process, employed and licensed by the Argonne National Laboratory, in order to obtain full concentration gradient.

During precipitation, the $\mathrm{Ni}$ concentration of the solution is continuously decreased by adding Ni-poor, Mn, and Co rich solutions, which results in precursor particles with a Ni-rich core and Ni-depleted outer shell. The material with concentration gradient (ca. NMC622) outperformed the heterogeneous NMC622. In case of core-shell NMC, the Ni depletion is carried out using stepwise process. At first, NMC precursor particles are obtained via co-precipitation from a Ni-rich solution. As a sufficient degree of particle growth is reached, $\mathrm{Mn}$ and $\mathrm{Co}$ are replenished, so that particle growth 
continues in a Ni-poor solution. Hereby, a Ni-depleted shell evolves around the Ni-rich core [127]. In both full concentration gradient and core-shell materials, the calcination temperature for lithiation must be kept relatively low to avoid transition metal diffusion and decomposition of the gradient [128].

Moreover, the considerations of cation doping and concentration gradients can be combined. Such a dopant concentration gradient is reported for aluminum [129]. Here, the inactive aluminum species stabilizes the surface of the Ni-rich NMC particle, whereas the capacity loss due to doping is diminished, since the overall amount of $\mathrm{Al}$ is smaller when compared to heterogeneous doping.

However, a lattice parameter mismatch is unavoidable in such materials, being linked to the difference in compositions, despite all of the beneficial features.

\subsection{Surface Modification}

The most upfront method to diminish that impact could be modifying the surface of the cathode particle/electrode and/or interfaces since most of the parasitic redox reactions in Ni-rich cathode materials occur at the surface and polarized interphases between the electrodes and electrolytes. Moreover, capacity fading through structural distortion commonly starts from the surface of the active cathode material and, thus, surface modifications (via surface coating) presents as one of the most sensible approaches. A great number of studies have been carried out while using different coating materials and techniques. These surface coating materials are both electrochemically and chemically inactive, enlisting metal oxides (e.g., $\mathrm{Al}_{2} \mathrm{O}_{3}, \mathrm{SiO}_{2}$, etc.), fluorides (e.g., $\mathrm{AlF}_{3}, \mathrm{FeF}_{3}$ etc.), phosphates (e.g., $\mathrm{AlPO}_{4}, \mathrm{Li}_{3} \mathrm{PO}_{4}$ etc.), lithium transition metal oxides (e.g., $\mathrm{LiVO}_{3}$ ), conductive polymeric, and interfacial layers [130]. In general, there are two types of coatings. On one side, the non-conductive ones, where alumina is mostly the material of choice due to its high stability, and the other type is the conductive coating, i.e., Li ion conductive. However, coating always increases the resistance and thus minimization or optimization of the coating thickness is necessary. In view of this, atomic layer deposition (ALD) is one of the most widely utilized methods of interest for coating. It offers the possibility to deposit film layer by layer onto the particle, thus enabling proper control on the thickness of the film. Figure 14 shows the possible mechanism of NMC coating while using $\mathrm{AlPO}_{4}$ and $\mathrm{Al}_{2} \mathrm{O}_{3}$ [131].

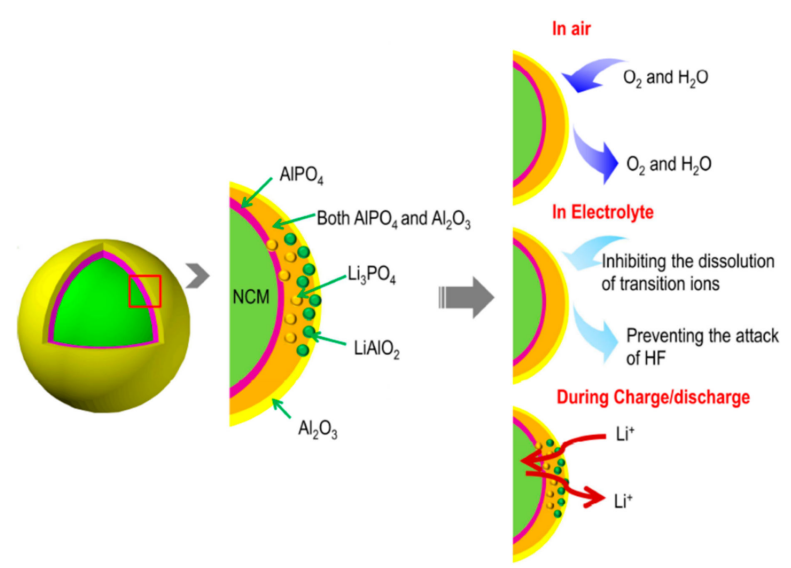

Figure 14. Possible mechanism of double-coated NMC cathode material, using $\mathrm{Al}_{2} \mathrm{O}_{3}$ and $\mathrm{AlPO}_{4}$. Reproduced from Ref. [130] with permission, Copyright 2017, Elsevier.

\subsection{Functional Electrolyte Additives}

The use of electrolyte additives presents to be the most efficient and economic means towards solving the multifaceted hurdles that are associated with nickel rich cathode materials [75]. The additives, which are incorporated in small doses, can play multiple roles, including as cation stabilizers, reactive oxygen radicals and HF scavengers, robust cathode-electrolyte interphase (CEI) builders, surface modifiers, etc., without altering the bulk properties of the electrolyte system. Among 
many others, fluorinated molecules, such as Methyl (2, 2, 2-Trifluoroethyl) carbonate (FEMC) [132], bi-lithium difluoro(oxalato)borate, pentafluorophenylisocyanate, Lithium difluoro (oxalate) borate (LiDFOB) [133], lithium difluorophosphate $\left(\mathrm{Li}_{2} \mathrm{PO}_{2} \mathrm{~F}_{2}\right)$, tris(2,2,2,-trifluoroethyl) phosphite (TTFP) [134], triphenylphosphine oxide boron trifluorid (TPPO-BF) [135], and other functional groups, such as bi-functional tris(trimethylsilyl) phosphate, (2-cyanoethyl) triethoxysilane, etc., are among the investigated additives and they proved to prevent transition metal dissolution and/or oxygen leaching owing to the formation of effective passivation layers both on the anode and cathode surfaces. Some additives with strong anion coordination effect, for instance tris (pentafluorophenyl) borane (TPFPB), are known to trap highly reactive oxygen species $\left(\mathrm{O}_{2}{ }^{2-} / \mathrm{O}_{2}{ }^{-}\right)$or radicals $\left(\mathrm{O}_{2}{ }^{\ddot{Y}}-\mathrm{O}^{\ddot{Y}-}\right)$ that will otherwise oxidize the electrolyte and induce structural transformation [136]. Figure 15a,b show the enabling effect of sample additives (i.e., silyl-functionalized dimethoxydimethylsilane and blend of FEMC and VC) on Ni-rich cathode materials [137,138].

a)

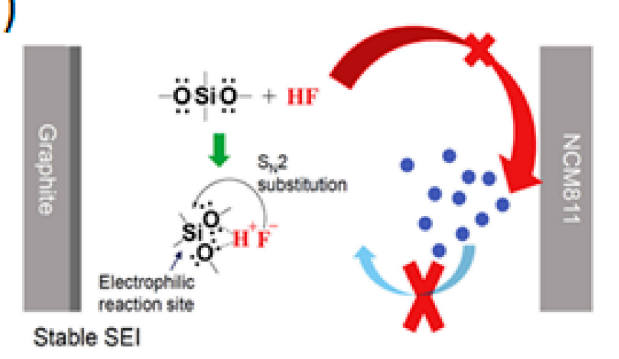

b)

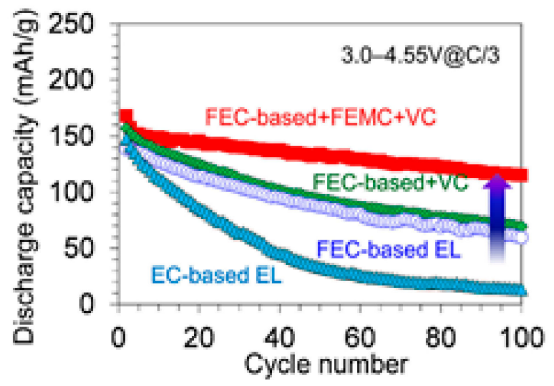

Figure 15. (a) Effect of silyl-functionalized dimethoxydimethylsilane additive on the surface stability of both high voltage Ni rich cathode and anode, adopted from Ref [138] with permission, Copyright 2018, Elsevier (b) Cycling performance, of the $\mathrm{LiNi}_{0.5} \mathrm{Co}_{0.2} \mathrm{Mn}_{0.3} \mathrm{O}_{2} /$ Si-graphite in $1 \mathrm{M} \mathrm{LiPF} / \mathrm{FEC}$ : DEC electrolyte with out and with blended additives of FEMC-VC, obtained from Ref [137] with permission, Copyright 2016, Elsevier.

\subsection{Designer Polymeric Binders}

Though there is not much data regarding the utilization of tailored polymeric binders endowed with synergistic effects for Ni-rich cathode materials, i.e., with binding and filming roles, the exploration of functionalized polymeric binders could be one potential research focus to address the challenges mentioned above. A binder with special moieties could lead to the formation of a robust cathode-electrolyte interphase (CEI) and thereby prevent the drawbacks that are associated with NMC cathode materials [8,139].

\section{Conclusions}

The market penetration of emerging applications, such as the electro mobility and efficient integration of green energy sources into the energy mix, sturdily demands high energy density batteries, i.e., $\sim 2.5$ times more energy than the contemporary LIB can store. Advanced cathode materials are needed to meet this goal. As near-term candidates, the development of nickel (Ni)-rich cathodes have harvested huge attention from the scientific, government, and industry sectors. Ni-rich ternary-layered cathodes are characterized by high capacity, improved rate capability, lower material cost and reduced transition metal dissolution. However, the presence of various hurdles, mainly induced by the increment in Ni content, hinders the widespread commercialization of these type cathodes. These include high surface reactivity, leading to electrolyte decomposition and oxygen evolution reaction, $\mathrm{Ni}^{2+} / \mathrm{Li}^{+}$mixing, phase (spine-to-rock salt type) transition, micro cracking, transition metal dissolution, and the migration of partially soluble salts to anode and thereby contaminating it etc. In response to such challenges, numerous research groups have suggested various mitigating strategies, including anion and cation doping/substitution, surface modification, deployment of role-specific electrolyte 
additives, polymeric binders, etc. In general, potential future research directions can be summarized, as follows:

(i) Novel electrolyte design: The development of designer electrolyte salt anions and tailored electrolyte additives presents as one of the emerging avenues for the realization of high-voltage nickel rich cathode materials. Salt anions stable at high voltage and those do not result in the formation of reactive species are needed. On the additive side, molecules or ionic salts of multi-functionality and/or single functionality with synergistic effect are desirable.

(ii) Degradation phenomenon: The chemistry, major routes, and ultimate effects of the different degradation mechanisms require an exhaustive investigation and understanding. Of particular interest, the cathode/electrolyte interface and its dialogue with the anode and/or anode-electrolyte interface is of supreme importance and it deserves a deep characterization and, thus, comprehension while using innovative experimental and theoretical calculations. Moreover, the quantification of the different aging behaviors and understanding of the correlations among the various degradation mechanisms of Ni-rich cathode materials will be highly appreciated.

(iii) Safety appraisal: The full-scale safety profiling of high voltage and Ni-rich cathode materials is one of the stern requirement for practical operations and it needs an in-depth investigation enlisting both thermal and chemical threats making use of various arsenal characterization tools.

(iv) Advanced characterization: The use of nondestructive advanced characterization tools is required to better understand and profile the degradation and aging routes.

Author Contributions: Conceptualization, P.T. and G.G.E.; software, P.T.; writing-original draft preparation, P.T.; writing-review and editing, G.G.E. and H.J.; visualization, P.T. and G.G.E.; supervision, E.F. All authors have read and agreed to the published version of the manuscript.

Funding: This research received no external funding.

Conflicts of Interest: The authors declare no conflict of interest. (Disclaimer: The results, opinions and conclusions expressed in this thesis are not necessarily those of Volkswagen Aktiengesellschaft).

\section{References}

1. Eshetu, G.G.; Armand, M.; Ohno, H.; Scrosati, B.; Passerini, S. Ionic Liquids as Tailored Media for the Synthesis and Processing of Energy Conversion Materials. Energy Environ. Sci. 2016, 9, 49-61. [CrossRef]

2. Zhang, H.; Eshetu, G.G.; Judez, X.; Li, C.; Rodriguez-Martínez, L.M.; Armand, M. Electrolyte Additives for Lithium Metal Anodes and Rechargeable Lithium Metal Batteries: Progress and Perspectives. Angew. Chem. 2018, 57. [CrossRef] [PubMed]

3. Olivetti, E.A.; Ceder, G.; Gaustad, G.G.; Fu, X. Lithium-Ion Battery Supply Chain Considerations: Analysis of Potential Bottlenecks in Critical Metals. Joule 2017, 1, 229-243. [CrossRef]

4. Eshetu, G.G.; Mecerreyes, D.; Forsyth, M.; Zhang, H.; Armand, M. Polymeric Ionic Liquids for Lithium-Based Rechargeable Batteries. Mol. Syst. Des. Eng. 2019, 4, 294-309. [CrossRef]

5. Ryu, H.H.; Park, K.J.; Yoon, D.R.; Aishova, A.; Yoon, C.S.; Sun, Y.K. Li[ $\left[\mathrm{Ni}_{0.9} \cdot \mathrm{Co}_{0.09} \mathrm{~W}_{0.01}\right]_{2}$ : A New Type of Layered Oxide Cathode with High Cycling Stability. Adv. Energy Mater. 2019, 9, 1902698. [CrossRef]

6. Winter, M.; Barnett, B.; Xu, K. Before Li Ion Batteries. Chem. Rev. 2018, 118, 11433-11456. [CrossRef]

7. Eshetu, G.G.; Figgemeier, E. Confronting the Challenges of Next-Generation Silicon Anode-Based Lithium-Ion Batteries: Role of Designer Electrolyte Additives and Polymeric Binders. ChemSusChem 2019, 12, 2515-2539. [CrossRef]

8. Goodenough, J.B.; Kim, Y. Spherical Carbon Particles are Used for Efficient and Stable “Metal Lithium Storage Room". Chem. Mater. 2010, 22, 587-603. [CrossRef]

9. Armand, M. Nature Lithium Battery. Nature 2001, 414, 359-367. [CrossRef]

10. Liu, C.; Neale, Z.G.; Cao, G. Understanding Electrochemical Potentials of Cathode Materials in Rechargeable Batteries. Mater. Today 2016, 19, 109-123. [CrossRef]

11. Lee, S.H.; Lee, S.; Jin, B.S.; Kim, H.S. Optimized Electrochemical Performance of Ni Rich $\mathrm{LiNi}_{0.91} \mathrm{Co}_{0.06} \mathrm{Mn}_{0.03} \mathrm{O}_{2}$ Cathodes for High-Energy Lithium Ion Batteries. Sci. Rep. 2019, 9, 8901. [CrossRef] [PubMed] 
12. Manthiram, A.; Song, B.; Li, W. A Perspective on Nickel-Rich Layered Oxide Cathodes for Lithium-Ion Batteries. Energy Storage Mater. 2017, 6, 125-139. [CrossRef]

13. Mizushima, K.; Jones, P.C.; Wiseman, P.J.; Goodenough, J.B. $\mathrm{Li}_{x} \mathrm{CoO}_{2}(0<x<1)$ : A new cathode material for batteries of high energy density. Mater. Res. Bulletin 1980, 15, 783-789. [CrossRef]

14. Choi, J.W.; Aurbach, D. Promise and Reality of Post-Lithium-Ion Batteries with High Energy Densities. Nat. Rev. Mater. 2016, 1, 16013. [CrossRef]

15. Schmidt, T.; Buchert, M.; Schebek, L. Investigation of the Primary Production Routes of Nickel and Cobalt Products Used for Li-Ion Batteries. Resour. Conserv. Recycl. 2016, 112, 107-122. [CrossRef]

16. Xu, B.; Qian, D.; Wang, Z.; Meng, Y.S. Recent Progress in Cathode Materials Research for Advanced Lithium Ion Batteries. Mater. Sci. Eng. R Rep. 2012, 73, 51-65. [CrossRef]

17. Zhang, W.J. Structure and Performance of $\mathrm{LiFePO}_{4}$ Cathode Materials: A Review. J. Power Sources 2011, 196, 2962-2970. [CrossRef]

18. Kasnatscheew, J.; Winter, M. Thorough Look by Consideration of the $\mathrm{Li}^{+}$Extraction Ratio. ACS Appl. Energy Mater. 2019, 2, 7733-7737. [CrossRef]

19. Hou, P.; Yin, J.; Ding, M.; Huang, J.; Xu, X. Surface/Interfacial Structure and Chemistry of High-Energy Nickel-Rich Layered Oxide Cathodes: Advances and Perspectives. Small 2017, 13, 1-29. [CrossRef]

20. Myung, S.T.; Maglia, F.; Park, K.J.; Yoon, C.S.; Lamp, P.; Kim, S.J.; Sun, Y.K. Nickel-Rich Layered Cathode Materials for Automotive Lithium-Ion Batteries: Achievements and Perspectives. ACS Energy Lett. 2017, 2, 196-223. [CrossRef]

21. Liu, W.; Oh, P.; Liu, X.; Lee, M.J.; Cho, W.; Chae, S.; Kim, Y.; Cho, J. Nickel-Rich Layered Lithium Transition-Metal Oxide for High-Energy Lithium-Ion Batteries. Angew. Chem. 2015, 54, 4440-4457. [CrossRef] [PubMed]

22. Rozier, P.; Tarascon, J.M. Review-Li-Rich Layered Oxide Cathodes for next-Generation Li-Ion Batteries: Chances and Challenges. J. Electrochem. Soc. 2015, 162, A2490-A2499. [CrossRef]

23. Hannan, M.A.; Hoque, M.M.; Hussain, A.; Yusof, Y.; Ker, P.J. State-of-the-Art and Energy Management System of Lithium-Ion Batteries in Electric Vehicle Applications: Issues and Recommendations. IEEE Access 2018, 6, 19362-19378. [CrossRef]

24. Miao, Y.; Hynan, P.; Von Jouanne, A.; Yokochi, A. Current Li-Ion Battery Technologies in Electric Vehicles and Opportunities for Advancements. Energies 2019, 12, 1074. [CrossRef]

25. Zeng, X.; Li, M.; Abd El-Hady, D.; Alshitari, W.; Al-Bogami, A.S.; Lu, J.; Amine, K. Commercialization of Lithium Battery Technologies for Electric Vehicles. Adv. Energy Mater. 2019, 1900161, 1-25. [CrossRef]

26. Schmuch, R.; Wagner, R.; Hörpel, G.; Placke, T.; Winter, M. Performance and cost of materials for lithium-based rechargeable automotive batteries. Nat. Energy 2018, 3, 267. [CrossRef]

27. Wangda, L.; Erickson, E.M.; Arumugam, M. High-nickel layered oxide cathodes for lithium-based automotive batteries. Nat. Energy 2020, 5, 26-34. [CrossRef]

28. Ajayi, B.P.; Thapa, A.K.; Cvelbar, U.; Jasinski, J.B.; Sunkara, M.K. Atmospheric Plasma Spray Pyrolysis of Lithiated Nickel-Manganese-Cobalt Oxides for Cathodes in Lithium Ion Batteries. Chem. Eng. Sci. 2017, 174, 302-310. [CrossRef]

29. Križan, G.; Križan, J.; Dominko, R.; Gaberšček, M. Pulse Combustion Reactor as a Fast and Scalable Synthetic Method for Preparation of Li-Ion Cathode Materials. J. Power Sources 2017, 363, 218-226. [CrossRef]

30. Kim, D.; Shim, H.C.; Yun, T.G.; Hyun, S.; Han, S.M. High Throughput Combinatorial Analysis of Mechanical and Electrochemical Properties of $\mathrm{Li}\left[\mathrm{Ni}_{x} \mathrm{Co}_{y} \mathrm{Mn}_{z}\right] \mathrm{O}_{2}$ Cathode. Extrem. Mech. Lett. 2016, 9, 439-448. [CrossRef]

31. Sun, Y.K.; Chen, Z.; Noh, H.J.; Lee, D.J.; Jung, H.G.; Ren, Y.; Wang, S.; Yoon, C.S.; Myung, S.T.; Amine, K. Nanostructured High-Energy Cathode Materials for Advanced Lithium Batteries. Nat. Mater. 2012, 11, 942-947. [CrossRef] [PubMed]

32. Ren, D.; Shen, Y.; Yang, Y.; Shen, L.; Levin, B.D.A.; Yu, Y.; Muller, D.A.; Abruña, H.D. Systematic Optimization of Battery Materials: Key Parameter Optimization for the Scalable Synthesis of Uniform, High-Energy, and High Stability LiNi ${ }_{0.6} \mathrm{Mn}_{0.2} \mathrm{Co}_{0.2} \mathrm{O}_{2}$ Cathode Material for Lithium-Ion Batteries. ACS Appl. Mater. Interfaces 2017, 9, 35811-35819. [CrossRef] [PubMed]

33. Peralta, D.; Salomon, J.; Colin, J.F.; Boulineau, A.; Fabre, F.; Bourbon, C.; Amestoy, B.; Gutel, E.; Bloch, D.; Patoux, S. Submicronic $\mathrm{LiNi}_{1 / 3} \mathrm{Mn}_{1 / 3} \mathrm{Co}_{1 / 3} \mathrm{O}_{2}$ Synthesized by Co-Precipitation for Lithium Ion Batteries-Tailoring a Classic Process for Enhanced Energy and Power Density. J. Power Sources 2018, 396, 527-532. [CrossRef] 
34. Tian, C.; Xu, Y.; Nordlund, D.; Lin, F.; Liu, J.; Sun, Z.; Liu, Y.; Doeff, M. Charge Heterogeneity and Surface Chemistry in Polycrystalline Cathode Materials. Joule 2018, 2, 464-477. [CrossRef]

35. Arai, H.; Okada, S.; Ohtsuka, H.; Ichimura, M.; Yamaki, J. Characterization and Cathode Performance of $\mathrm{Li}_{1}$ $-\mathrm{XNi}_{1}+\mathrm{XO}_{2}$ Prepared with the Excess Lithium Method. Solid State Ion. 1995, 80, 261-269. [CrossRef]

36. Oh, P.; Song, B.; Li, W.; Manthiram, A. Overcoming the Chemical Instability on Exposure to Air of Ni-Rich Layered Oxide Cathodes by Coating with Spinel LiMn ${ }_{1.9} \mathrm{~A}_{10.1} \mathrm{O}_{4}$. J. Mater. Chem. A 2016, 4, 5839-5841. [CrossRef]

37. Cho, D.H.; Jo, C.H.; Cho, W.; Kim, Y.J.; Yashiro, H.; Sun, Y.K.; Myung, S.T. Effect of Residual Lithium Compounds on Layer Ni-Rich $\mathrm{Li}\left[\mathrm{Ni}_{0.7} \mathrm{Mn}_{0.3}\right] \mathrm{O}_{2}$. J. Electrochem. Soc. 2014, 161, 920-926. [CrossRef]

38. Zhang, S.S. Insight into the Gassing Problem of Li-Ion Battery. Front. Energy Res. 2014, 2, 2-5. [CrossRef]

39. Dahn, J.R.; Fuller, E.W.; Obrovac, M.; von Sacken, U. Thermal Stability of $\mathrm{Li}_{x} \mathrm{CoO}_{2}, \mathrm{LixNiO}_{2}$ and $\lambda-\mathrm{MnO}_{2}$ and Consequences for the Safety of Li-Ion Cells. Solid State Ion. 1994, 69, 265-270. [CrossRef]

40. Hatsukade, T.; Schiele, A.; Hartmann, P.; Brezesinski, T.; Janek, J. Origin of Carbon Dioxide Evolved during Cycling of Nickel-Rich Layered NCM Cathodes. ACS Appl. Mater. Interfaces 2018, 10, 38892-38899. [CrossRef]

41. Wang, Y.; Jiang, J.; Dahn, J.R. The Reactivity of Delithiated $\mathrm{Li}\left(\mathrm{Ni}_{1 / 3} \mathrm{Co}_{1 / 3} \mathrm{Mn}_{1 / 3}\right) \mathrm{O}_{2}, \mathrm{Li}\left(\mathrm{Ni}_{0.8} \mathrm{Co}_{0.15} \mathrm{Al}_{0.05}\right) \mathrm{O}_{2}$ or $\mathrm{LiCoO}_{2}$ with Non-Aqueous Electrolyte. Electrochem. Commun. 2007, 9, 2534-2540. [CrossRef]

42. Jo, C.H.; Cho, D.H.; Noh, H.J.; Yashiro, H.; Sun, Y.K.; Myung, S.T. An Effective Method to Reduce Residual Lithium Compounds on Ni-Rich $\mathrm{Li}\left[\mathrm{Ni}_{0.6} \mathrm{Co}_{0.2} \mathrm{Mn}_{0.2}\right] \mathrm{O}_{2}$ Active Material Using a Phosphoric Acid Derived Li3PO4 Nanolayer. Nano Res. 2015, 8, 1464-1479. [CrossRef]

43. Kim, U.H.; Jun, D.W.; Park, K.J.; Zhang, Q.; Kaghazchi, P.; Aurbach, D.; Major, D.T.; Goobes, G.; Dixit, M.; Leifer, N.; et al. Pushing the Limit of Layered Transition Metal Oxide Cathodes for High-Energy Density Rechargeable Li Ion Batteries. Energy Environ. Sci. 2018, 11, 1271-1279. [CrossRef]

44. Schipper, F.; Erickson, E.M.; Erk, C.; Shin, J.Y.; Chesneau, F.F.; Aurbach, D. Review-Recent Advances and Remaining Challenges for Lithium Ion Battery Cathodes I. Nickel-Rich, $\mathrm{LiNi}_{x} \mathrm{Co}_{y} \mathrm{Mn}_{z} \mathrm{O}_{2}$. J. Electrochem. Soc. 2017, 164, A6220-A6228. [CrossRef]

45. Li, T.; Yuan, X.-Z.; Zhang, L.; Song, D.; Shi, K.; Bock, C. Degradation Mechanisms and Mitigation Strategies of Nickel-Rich NMC-Based Lithium-Ion Batteries; Springer: Singapore, 2019; Volume 2018. [CrossRef]

46. Tang, M.; Yang, J.; Chen, N.; Zhu, S.; Wang, X.; Wang, T.; Zhang, C.; Xia, Y. Overall Structural Modification of a Layered Ni-Rich Cathode for Enhanced Cycling Stability and Rate Capability at High Voltage. J. Mater. Chem. A 2019, 7, 6080-6089. [CrossRef]

47. Shim, J.H.; Kim, C.Y.; Cho, S.W.; Missiul, A.; Kim, J.K.; Ahn, Y.J.; Lee, S. Effects of Heat-Treatment Atmosphere on Electrochemical Performances of Ni-Rich Mixed-Metal Oxide $\left(\mathrm{LiNi}_{0.8} \mathrm{Co}_{0.15} \mathrm{Mn}_{0.05} \mathrm{O}_{2}\right)$ as a Cathode Material for Lithium Ion Battery. Electrochim. Acta 2014, 138, 15-21. [CrossRef]

48. Lim, J.M.; Hwang, T.; Kim, D.; Park, M.S.; Cho, K.; Cho, M. Intrinsic Origins of Crack Generation in Ni-Rich $\mathrm{LiNi}_{0.8} \mathrm{Co}_{0.1} \mathrm{Mn}_{0.1} \mathrm{O}_{2}$ Layered Oxide Cathode Material. Sci. Rep. 2017, 7, 39669. [CrossRef]

49. Tian, C.; Nordlund, D.; Xin, H.L.; Xu, Y.; Liu, Y.; Sokaras, D.; Lin, F.; Doeff, M.M. Depth-Dependent Redox Behavior of $\mathrm{LiNi}_{0.6} \mathrm{Mn}_{0.2} \mathrm{Co}_{0.2} \mathrm{O}_{2}$. J. Electrochem. Soc. 2018, 165, A696-A704. [CrossRef]

50. Koyama, Y.; Yabuuchi, N.; Tanaka, I.; Adachi, H.; Ohzuku, T. Solid-State Chemistry and Electrochemistry of $\mathrm{LiCo}_{1 / 3} \mathrm{Ni}_{1 / 3} \mathrm{Mn}_{1 / 3} \mathrm{O}_{2}$ for Advanced Lithium-Ion Batteries I. First-Principles Calculation on the Crystal and Electronic Structures. J. Electrochem. Soc. 2004, 151, A1545-A1551. [CrossRef]

51. Bak, S.M.; Hu, E.; Zhou, Y.; Yu, X.; Senanayake, S.D.; Cho, S.J.; Kim, K.B.; Chung, K.Y.; Yang, X.Q.; Nam, K.W. Structural Changes and Thermal Stability of Charged $\mathrm{LiNi}_{x} \mathrm{Mn}_{y} \mathrm{Co}_{z} \mathrm{O}_{2}$ Cathode Materials Studied by Combined In Situ Time-Resolved XRD and Mass Spectroscopy. ACS Appl. Mater. Interfaces 2014, 6, 22594-22601. [CrossRef]

52. Jung, R.; Metzger, M.; Maglia, F.; Stinner, C.; Gasteiger, H.A. Chemical versus Electrochemical Electrolyte Oxidation on NMC111, NMC622, NMC811, LNMO, and Conductive Carbon. J. Phys. Chem. Lett. 2017, 8, 4820-4825. [CrossRef] [PubMed]

53. Bresser, D.; Buchholz, D.; Moretti, A.; Varzi, A.; Passerini, S. Alternative Binders for Sustainable Electrochemical Energy Storage-The Transition to Aqueous Electrode Processing and Bio-Derived Polymers. Energy Environ. Sci. 2018, 11, 3096-3127. [CrossRef]

54. Doberdò, I.; Löffler, N.; Laszczynski, N.; Cericola, D.; Penazzi, N.; Bodoardo, S.; Kim, G.-T.; Passerini, S. Enabling Aqueous Binders for Lithium Battery Cathodes-Carbon Coating of Aluminum Current Collector. J. Power Sources 2014, 248, 1000-1006. [CrossRef] 
55. Du, Z.; Rollag, K.M.; Li, J.; An, S.J.; Wood, M.; Sheng, Y.; Mukherjee, P.P.; Daniel, C.; Wood, D.L. Enabling Aqueous Processing for Crack-Free Thick Electrodes. J. Power Sources 2017, 354, 200-206. [CrossRef]

56. Ahmadi, L.; Young, S.B.; Fowler, M.; Fraser, R.A.; Achachlouei, M.A. A Cascaded Life Cycle: Reuse of Electric Vehicle Lithium-Ion Battery Packs in Energy Storage Systems. Int. J. Life Cycl. Assess. 2017, 22, 111-124. [CrossRef]

57. Pavoni, F.H.; Sita, L.E.; dos Santos, C.S.; da Silva, S.P.; da Silva, P.R.C.; Scarminio, J. LiCoO 2 Particle Size Distribution as a Function of the State of Health of Discarded Cell Phone Batteries. Powder Technol. 2018, 326, 78-83. [CrossRef]

58. Yang, Y.; Xu, S.; He, Y. Lithium Recycling and Cathode Material Regeneration from Acid Leach Liquor of Spent Lithium-Ion Battery via Facile Co-Extraction and Co-Precipitation Processes. Waste Manag. 2017, 64, 219-227. [CrossRef]

59. Yang, Y.; Huang, G.; Xu, S.; He, Y.; Liu, X. Thermal Treatment Process for the Recovery of Valuable Metals from Spent Lithium-Ion Batteries. Hydrometallurgy 2016, 165, 390-396. [CrossRef]

60. Zheng, X.; Gao, W.; Zhang, X.; He, M.; Lin, X.; Cao, H.; Zhang, Y.; Sun, Z. Spent Lithium-Ion Battery Recycling-Reductive Ammonia Leaching of Metals from Cathode Scrap by Sodium Sulphite. Waste Manag. 2017, 60, 680-688. [CrossRef]

61. Mohtat, P.; Nezampasandarbabi, F.; Mohan, S.; Siegel, J.B.; Stefanopoulou, A.G.; James, A.; Uddin, K.; Chouchelamane, G.H.; Suttman, A.; Gong, X.; et al. Aging Phenomena for Lithium-Ion Batteries. J. Power Sources 2017, 147, 98-103. [CrossRef]

62. Waldmann, T.; Iturrondobeitia, A.; Kasper, M.; Ghanbari, N.; Aguesse, F.; Bekaert, E.; Daniel, L.; Genies, S.; Gordon, I.J.; Löble, M.W.; et al. Review-Post-Mortem Analysis of Aged Lithium-Ion Batteries: Disassembly Methodology and Physico-Chemical Analysis Techniques. J. Electrochem. Soc. 2016, 163, A2149-A2164. [CrossRef]

63. Wu, Y.; Saxena, S.; Xing, Y.; Wang, Y.; Li, C.; Yung, W.K.C.; Pecht, M. Analysis of Manufacturing-Induced Defects and Structural Deformations in Lithium-Ion Batteries Using Computed Tomography. Energies 2018, 11, 925. [CrossRef]

64. Li, J.; Du, Z.; Ruther, R.E.; An, S.J.; David, L.A.; Hays, K.; Wood, M.; Phillip, N.D.; Sheng, Y.; Mao, C.; et al. Toward Low-Cost, High-Energy Density, and High-Power Density Lithium-Ion Batteries. JOM 2017, 69, 1484-1496. [CrossRef]

65. Mohanty, D.; Hockaday, E.; Li, J.; Hensley, D.K.; Daniel, C.; Wood, D.L. Effect of Electrode Manufacturing Defects on Electrochemical Performance of Lithium-Ion Batteries: Cognizance of the Battery Failure Sources. J. Power Sources 2016, 312, 70-79. [CrossRef]

66. Mohanty, D.; Li, J.; Born, R.; Maxey, L.C.; Dinwiddie, R.B.; Daniel, C.; Wood, D.L. Non-Destructive Evaluation of Slot-Die-Coated Lithium Secondary Battery Electrodes by in-Line Laser Caliper and IR Thermography Methods. Anal. Methods 2014, 6, 674-683. [CrossRef]

67. Birkl, C.R.; Roberts, M.R.; McTurk, E.; Bruce, P.G.; Howey, D.A. Degradation Diagnostics for Lithium Ion Cells. J. Power Sources 2017, 341, 373-386. [CrossRef]

68. Dahn, H.M.; Smith, A.J.; Burns, J.C.; Stevens, D.A.; Dahn, J.R. User-Friendly Differential Voltage Analysis Freeware for the Analysis of Degradation Mechanisms in Li-Ion Batteries. J. Electrochem. Soc. 2012, 159, A1405-A1409. [CrossRef]

69. Gabrisch, H.; Yi, T.; Yazami, R. Transmission Electron Microscope Studies of $\mathrm{LiNi}_{1 / 3} \mathrm{Mn}_{1 / 3} \mathrm{Co}_{1 / 3} \mathrm{O}_{2}$ before and after Long-Term Aging at $70^{\circ} \mathrm{C}$. Electrochem. Solid-State Lett. 2008, 11, 7-12. [CrossRef]

70. Mu, L.; Lin, R.; Xu, R.; Han, L.; Xia, S.; Sokaras, D.; Steiner, J.D.; Weng, T.C.; Nordlund, D.; Doeff, M.M.; et al. Oxygen Release Induced Chemomechanical Breakdown of Layered Cathode Materials. Nano Lett. 2018, 18, 3241-3249. [CrossRef]

71. Jung, S.K.; Gwon, H.; Hong, J.; Park, K.Y.; Seo, D.H.; Kim, H.; Hyun, J.; Yang, W.; Kang, K. Understanding the Degradation Mechanisms of $\mathrm{LiNi}_{0.5} \mathrm{Co}_{0.2} \mathrm{Mn}_{0.3} \mathrm{O}_{2}$ Cathode Material in Lithium Ion Batteries. Adv. Energy Mater. 2014, 4, 1-7. [CrossRef]

72. Li, J.; Downie, L.E.; Ma, L.; Qiu, W.; Dahn, J.R. Study of the Failure Mechanisms of $\operatorname{LiNi}_{0.8} \mathrm{Mn}_{0.1} \mathrm{Co}_{0.1} \mathrm{O}_{2}$ Cathode Material for Lithium Ion Batteries. J. Electrochem. Soc. 2015, 162, A1401-A1408. [CrossRef]

73. Jung, R.; Metzger, M.; Maglia, F.; Stinner, C.; Gasteiger, H.A. Oxygen Release and Its Effect on the Cycling Stability of $\mathrm{LiNi}_{\mathrm{x}} \mathrm{Mn}_{\mathrm{y}} \mathrm{Co}_{\mathrm{z}} \mathrm{O}_{2}(\mathrm{NMC})$ Cathode Materials for Li-Ion Batteries. J. Electrochem. Soc. 2017, 164, A1361-A1377. [CrossRef] 
74. Nam, K.W.; Yoon, W.S.; Yang, X.Q. Structural Changes and Thermal Stability of Charged $\operatorname{LiNi}_{1 / 3} \mathrm{Co}_{1 / 3} \mathrm{Mn}_{1 / 3} \mathrm{O}_{2}$ Cathode Material for Li-Ion Batteries Studied by Time-Resolved XRD. J. Power Sources 2009, 189, 515-518. [CrossRef]

75. Young, D.; Park, I.; Shin, Y.; Seo, D.; Kang, Y.; Doo, S.; Koh, M. Ni-Stabilizing Additives for Completion of Ni-Rich Layered Cathode Systems in Lithium-Ion Batteries: An Ab Initio Study. J. Power Sources 2019, 418, 74-83. [CrossRef]

76. Zhang, Y.; Katayama, Y.; Tatara, R.; Giordano, L.; Yu, Y.; Fraggedakis, D.; Sun, J.; Maglia, F.; Jung, R.; Bazant, M.Z.; et al. Revealing Electrolyte Oxidation via Carbonate Dehydrogenation on Ni-Based Oxides in Li-Ion Batteries by in Situ Fourier Transform Infrared Spectroscopy. Energy Environ. Sci. 2019. [CrossRef]

77. Lin, F.; Markus, I.M.; Nordlund, D.; Weng, T.C.; Asta, M.D.; Xin, H.L.; Doeff, M.M. Surface Reconstruction and Chemical Evolution of Stoichiometric Layered Cathode Materials for Lithium-Ion Batteries. Nat. Commun. 2014, 5, 3529. [CrossRef]

78. Kim, J.M.; Chung, H.T. Role of Transition Metals in Layered $\mathrm{Li}[\mathrm{Ni}, \mathrm{Co}, \mathrm{Mn}] \mathrm{O}_{2}$ under Electrochemical Operation. Electrochim. Acta 2004, 49, 3573-3580. [CrossRef]

79. Kondrakov, A.O.; Schmidt, A.; Xu, J.; Geßwein, H.; Mönig, R.; Hartmann, P.; Sommer, H.; Brezesinski, T.; Janek, J. Anisotropic Lattice Strain and Mechanical Degradation of High- and Low-Nickel NCM Cathode Materials for Li-Ion Batteries. J. Phys. Chem. C 2017, 121, 3286-3294. [CrossRef]

80. Li, X.; Qiao, Y.; Guo, S.; Xu, Z.; Zhu, H.; Zhang, X.; Yuan, Y.; He, P.; Ishida, M.; Zhou, H. Direct Visualization of the Reversible $\mathrm{O}^{2-} / \mathrm{O}^{-}$Redox Process in Li-Rich Cathode Materials. Adv. Mater. 2018, 30, 2-7. [CrossRef]

81. Nation, L.; Li, J.; James, C.; Qi, Y.; Dudney, N.; Sheldon, B.W. In Situ Stress Measurements during Electrochemical Cycling of Lithium-Rich Cathodes. J. Power Sources 2017, 364, 383-391. [CrossRef]

82. Ko, D.S.; Park, J.H.; Park, S.; Ham, Y.N.; Ahn, S.J.; Park, J.H.; Han, H.N.; Lee, E.; Jeon, W.S.; Jung, C. Microstructural Visualization of Compositional Changes Induced by Transition Metal Dissolution in Ni-Rich Layered Cathode Materials by High-Resolution Particle Analysis. Nano Energy 2019, 56, 434-442. [CrossRef]

83. Li, Y.; Cheng, X.; Zhang, Y.; Zhao, K. Recent Advance in Understanding the Electro-Chemo-Mechanical Behavior of Lithium-Ion Batteries by Electron Microscopy. Mater. Today Nano 2019, 7, 100040. [CrossRef]

84. Ruan, Y.; Song, X.; Fu, Y.; Song, C.; Battaglia, V. Structural Evolution and Capacity Degradation Mechanism of $\mathrm{LiNi}_{0.6} \mathrm{Mn}_{0.2} \mathrm{Co}_{0.2} \mathrm{O}_{2}$ Cathode Materials. J. Power Sources 2018, 400, 539-548. [CrossRef]

85. Besli, M.M.; Xia, S.; Kuppan, S.; Huang, Y.; Metzger, M.; Shukla, A.K.; Schneider, G.; Hellstrom, S.; Christensen, J.; Doeff, M.M.; et al. Mesoscale Chemomechanical Interplay of the $\operatorname{LiNi}_{0.8} \mathrm{Co}_{0.15} \mathrm{Al}_{0.05} \mathrm{O}_{2}$ Cathode in Solid-State Polymer Batteries. Chem. Mater. 2019, 31, 491-501. [CrossRef]

86. Nara, H.; Morita, K.; Mukoyama, D.; Yokoshima, T.; Momma, T.; Osaka, T. Impedance Analysis of $\mathrm{LiNi}_{1 / 3} \mathrm{Mn}_{1 / 3} \mathrm{Co}_{1 / 3} \mathrm{O}_{2}$ Cathodes with Different Secondary-Particle Size Distribution in Lithium-Ion Battery. Electrochim. Acta 2017, 241, 323-330. [CrossRef]

87. Zhang, S.S. Understanding of Performance Degradation of $\mathrm{LiNi}_{0.80} \mathrm{Co}_{0.10} \mathrm{Mn}_{0.10} \mathrm{O}_{2}$ Cathode Material Operating at High Potentials. J. Energy Chem. 2020, 41, 135-141. [CrossRef]

88. Nowak, S.; Winter, M. The Role of Cations on the Performance of Lithium Ion Batteries: A Quantitative Analytical Approach. Acc. Chem. Res. 2018, 51, 265-272. [CrossRef]

89. Hwang, S.; Kim, S.Y.; Chung, K.Y.; Stach, E.A.; Kim, S.M.; Chang, W. Determination of the Mechanism and Extent of Surface Degradation in Ni-Based Cathode Materials after Repeated Electrochemical Cycling. APL Mater. 2016, 4. [CrossRef]

90. Zhao, W.; Zheng, J.; Zou, L.; Jia, H.; Liu, B.; Wang, H.; Engelhard, M.H.; Wang, C.; Xu, W.; Yang, Y.; et al. High Voltage Operation of Ni-Rich NMC Cathodes Enabled by Stable Electrode/Electrolyte Interphases. Adv. Energy Mater. 2018, 8. [CrossRef]

91. Xiong, D.J.; Ellis, L.D.; Li, J.; Li, H.; Hynes, T.; Allen, J.P.; Xia, J.; Hall, D.S.; Hill, I.G.; Dahn, J.R. Measuring Oxygen Release from Delithiated LiNixMnyCo $\mathrm{Co}_{-x-y} \mathrm{O}_{2}$ and Its Effects on the Performance of High Voltage Li-Ion Cells. J. Electrochem. Soc. 2017, 164, A3025-A3037. [CrossRef]

92. Hu, E.; Wang, X.; Yu, X.; Yang, X.Q. Probing the Complexities of Structural Changes in Layered Oxide Cathode Materials for Li-Ion Batteries during Fast Charge-Discharge Cycling and Heating. Acc. Chem. Res. 2018, 51, 290-298. [CrossRef]

93. An, S.J.; Li, J.; Daniel, C.; Mohanty, D.; Nagpure, S.; Wood, D.L. The State of Understanding of the Lithium-Ion-Battery Graphite Solid Electrolyte Interphase (SEI) and Its Relationship to Formation Cycling. Carbon N. Y. 2016, 105, 52-76. [CrossRef] 
94. Shkrob, I.A.; Kropf, A.J.; Marin, T.W.; Li, Y.; Poluektov, O.G.; Niklas, J.; Abraham, D.P. Manganese in Graphite Anode and Capacity Fade in Li Ion Batteries. J. Phys. Chem. C 2014, 118, 24335-24348. [CrossRef]

95. Gilbert, J.A.; Shkrob, I.A.; Abraham, D.P. Transition Metal Dissolution, Ion Migration, Electrocatalytic Reduction and Capacity Loss in Lithium-Ion Full Cells. J. Electrochem. Soc. 2017, 164, A389-A399. [CrossRef]

96. Yeon, N.; Yim, T.; Ho, J.; Yu, J.; Lee, Z. Microstructural Study on Degradation Mechanism of Layered Electron Microscopy. J. Power Sources 2016, 307, 641-648. [CrossRef]

97. Guéguen, A.; Streich, D.; He, M.; Mendez, M.; Chesneau, F.F.; Novák, P.; Berg, E.J. Decomposition of LiPF6 in High Energy Lithium-Ion Batteries Studied with Online Electrochemical Mass Spectrometry. J. Electrochem. Soc. 2016, 163, A1095-A1100. [CrossRef]

98. Freiberg, A.T.S.; Roos, M.K.; Wandt, J.; De Vivie-Riedle, R.; Gasteiger, H.A. Singlet Oxygen Reactivity with Carbonate Solvents Used for Li-Ion Battery Electrolytes. J. Phys. Chem. A 2018, 122, 8828-8839. [CrossRef]

99. Waag, W.; Käbitz, S.; Sauer, D.U. Experimental Investigation of the Lithium-Ion Battery Impedance Characteristic at Various Conditions and Aging States and Its Influence on the Application. Appl. Energy 2013, 102, 885-897. [CrossRef]

100. Mu, L.; Yuan, Q.; Tian, C.; Wei, C.; Zhang, K.; Liu, J.; Pianetta, P.; Doeff, M.M.; Liu, Y.; Lin, F. Propagation Topography of Redox Phase Transformations in Heterogeneous Layered Oxide Cathode Materials. Nat. Commun. 2018, 9. [CrossRef]

101. Radin, M.D.; Hy, S.; Sina, M.; Fang, C.; Liu, H.; Vinckeviciute, J.; Zhang, M.; Whittingham, M.S.; Meng, Y.S.; Van der Ven, A. Narrowing the Gap between Theoretical and Practical Capacities in Li-Ion Layered Oxide Cathode Materials. Adv. Energy Mater. 2017, 7, 1-33. [CrossRef]

102. Solchenbach, S.; Metzger, M.; Egawa, M.; Beyer, H.; Gasteiger, H.A. Quantification of PF5 and POF3 from Side Reactions of LiPF6 in Li-Ion Batteries. J. Electrochem. Soc. 2018, 165, A3022-A3028. [CrossRef]

103. Pierre-Etienne, C.; David, P.; Mikael, C.; Pascal, M. Impact of Morphological Changes of $\operatorname{LiNi}_{1 / 3} \mathrm{Mn}_{1 / 3} \mathrm{Co}_{1 / 3} \mathrm{O}_{2}$ on Lithium-Ion Cathode Performances. J. Power Sources 2017, 346, 13-23. [CrossRef]

104. Chen, Z.; Wang, J.; Chao, D.; Baikie, T.; Bai, L.; Chen, S.; Zhao, Y.; Sum, T.C.; Lin, J.; Shen, Z. Hierarchical Porous $\mathrm{LiNi}_{1 / 3} \mathrm{Co}_{1 / 3} \mathrm{Mn}_{1 / 3} \mathrm{O}_{2}$ Nano-/Micro Spherical Cathode Material: Minimized Cation Mixing and Improved $\mathrm{Li}^{+}$Mobility for Enhanced Electrochemical Performance. Sci. Rep. 2016, 6, 25771. [CrossRef]

105. Wang, Y.; Roller, J.; Maric, R. Morphology-Controlled One-Step Synthesis of Nanostructured $\mathrm{LiNi}_{1 / 3} \mathrm{Mn}_{1 / 3} \mathrm{Co}_{1 / 3} \mathrm{O}_{2}$ Electrodes for Li-Ion Batteries. ACS Omega 2018, 3, 3966-3973. [CrossRef]

106. Li, J.; Li, H.; Stone, W.; Weber, R.; Hy, S.; Dahn, J.R. Synthesis of Single Crystal $\mathrm{LiNi}_{0.5} \mathrm{Mn}_{0.3} \mathrm{Co}_{0.2} \mathrm{O}_{2}$ for Lithium Ion Batteries. J. Electrochem. Soc. 2017, 164, A3529-A3537. [CrossRef]

107. Li, H.; Li, J.; Ma, X.; Dahn, J.R. Synthesis of Single Crystal LiNi ${ }_{0.6} \mathrm{Mn}_{0.2} \mathrm{Co}_{0.2} \mathrm{O}_{2}$ with Enhanced Electrochemical Performance for Lithium Ion Batteries. J. Electrochem. Soc. 2018, 165, A1038-A1045. [CrossRef]

108. Li, J.; Li, H.; Stone, W.; Glazier, S.; Dahn, J.R. Development of Electrolytes for Single Crystal NMC532/Artificial Graphite Cells with Long Lifetime. J. Electrochem. Soc. 2018, 165, A626-A635. [CrossRef]

109. Sharifi-Asl, S.; Chen, G.; Croy, J.; Balasubramanian, M.; Shahbazian-Yassar, R. Aberration-Corrected Scanning Transmission Electron Microscopy of Single Crystals and Chemically-Gradient NMC Cathodes. Microsc. Microanal. 2018, 24, 1536-1537. [CrossRef]

110. Xie, H.; Du, K.; Hu, G.; Peng, Z.; Cao, Y. The Role of Sodium in $\mathrm{LiNi}_{0.8} \mathrm{Co}_{0.15} \mathrm{Al}_{0.05} \mathrm{O}_{2}$ Cathode Material and Its Electrochemical Behaviors. J. Phys. Chem. C 2016, 120, 3235-3241. [CrossRef]

111. Pouillerie, C.; Croguennec, L.; Delmas, C. Modifications Observed Upon Cycling. Solid State Ion. 2000, 132, 15-29. [CrossRef]

112. Jang, Y.I.; Huang, B.; Wang, H.; Maskaly, G.R.; Ceder, G.; Sadoway, D.R.; Chiang, Y.M.; Liu, H.; Tamura, H. Synthesis and Characterization of $\mathrm{LiAl}_{y} \mathrm{CO}_{1-y} \mathrm{O}_{2}$ and $\mathrm{LiAl}_{\mathrm{y}} \mathrm{Ni}_{1-y} \mathrm{O}_{2}$. J. Power Sources 1999, 81, 589-593. [CrossRef]

113. Croguennec, L.; Suard, E.; Willmann, P.; Delmas, C. Structural and Electrochemical Characterization of the $\mathrm{LiNi}_{1-\mathrm{y}} \mathrm{Ti}_{\mathrm{y}} \mathrm{O}_{2}$ Electrode Materials Obtained by Direct Solid-State Reactions. Chem. Mater. 2002, 14, $2149-2157$. [CrossRef]

114. Zhang, X.; Jiang, W.J.; Mauger, A.; Gendron, F.; Julien, C.M. Minimization of the Cation Mixing in $\mathrm{Li}_{1+\mathrm{x}}(\mathrm{NMC})_{1-\mathrm{x}} \mathrm{O}_{2}$ as Cathode Material. J. Power Sources 2010, 195, 1292-1301. [CrossRef]

115. Nayak, P.K.; Erickson, E.M.; Schipper, F.; Penki, T.R.; Munichandraiah, N.; Adelhelm, P.; Sclar, H.; Amalraj, F.; Markovsky, B.; Aurbach, D. Review on Challenges and Recent Advances in the Electrochemical Performance of High Capacity Li- and Mn-Rich Cathode Materials for Li-Ion Batteries. Adv. Energy Mater. 2018, 8, 1-16. [CrossRef] 
116. Wang, R.; Qian, G.; Liu, T.; Li, M.; Liu, J.; Zhang, B.; Zhu, W.; Li, S.; Zhao, W.; Yang, W.; et al. Tuning Li-Enrichment in High-Ni Layered Oxide Cathodes to Optimize Electrochemical Performance for Li-Ion Battery. Nano Energy 2019, 62, 709-717. [CrossRef]

117. Tian, C.; Lin, F.; Doeff, M.M. Electrochemical Characteristics of Layered Transition Metal Oxide Cathode Materials for Lithium Ion Batteries: Surface, Bulk Behavior, and Thermal Properties. Acc. Chem. Res. 2018, 51, 89-96. [CrossRef]

118. Eilers-Rethwisch, M.; Winter, M.; Schappacher, F.M. Synthesis, Electrochemical Investigation and Structural Analysis of Doped $\mathrm{Li}\left[\mathrm{Ni}_{0.6} \mathrm{Mn}_{0.2} \mathrm{Co}_{0.2-\mathrm{x}} \mathrm{M}_{\mathrm{x}}\right] \mathrm{O}_{2}(\mathrm{x}=0,0.05 ; \mathrm{M}=\mathrm{Al}, \mathrm{Fe}, \mathrm{Sn})$ Cathode Materials. J. Power Sources 2018, 387, 101-107. [CrossRef]

119. Mi, C.; Han, E.; Li, L.; Zhu, L.; Cheng, F.; Dai, X. Effect of Iron Doping on $\mathrm{LiNi}_{0.35} \mathrm{Co}_{0.30} \mathrm{Mn}_{0.35} \mathrm{O}_{2}$. Solid State Ion. 2018, 325, 24-29. [CrossRef]

120. Weigel, T.; Schipper, F.; Erickson, E.M.; Susai, F.A.; Markovsky, B.; Aurbach, D. Structural and Electrochemical Aspects of $\mathrm{LiNi}_{0.8} \mathrm{Co}_{0.1} \mathrm{Mn}_{.1} \mathrm{O}_{2}$ Cathode Materials Doped by Various Cations. ACS Energy Lett. 2019, 4, 508-516. [CrossRef]

121. Zhao, Z.; Huang, B.; Wang, M.; Yang, X.; Gu, Y. Facile Synthesis of Fluorine Doped Single Crystal Ni-Rich Cathode Material for Lithium-Ion Batteries. Solid State Ion. 2019, 342, 115065. [CrossRef]

122. Konarov, A.; Myung, S.T.; Sun, Y.K. Cathode Materials for Future Electric Vehicles and Energy Storage Systems. ACS Energy Lett. 2017, 2, 703-708. [CrossRef]

123. Lin, F.; Nordlund, D.; Li, Y.; Quan, M.K.; Cheng, L.; Weng, T.C.; Liu, Y.; Xin, H.L.; Doeff, M.M. Metal Segregation in Hierarchically Structured Cathode Materials for High-Energy Lithium Batteries. Nat. Energy 2016, 1, 1-8. [CrossRef]

124. Hou, P.; Zhang, H.; Zi, Z.; Zhang, L.; Xu, X. Core-Shell and Concentration-Gradient Cathodes Prepared via Co-Precipitation Reaction for Advanced Lithium-Ion Batteries. J. Mater. Chem. A 2017, 5, 4254-4279. [CrossRef]

125. Sun, Y.K.; Myung, S.T.; Park, B.C.; Amine, K. Synthesis of Spherical Nano- To Microscale Core-Shell Particles $\mathrm{Li}\left[\left(\mathrm{Ni}_{0.8} \mathrm{Co}_{0.1} \mathrm{Mn}_{0.1}\right)_{1-\mathrm{x}}\left(\mathrm{Ni}_{0.5} \mathrm{Mn}_{0.5}\right)_{\mathrm{x}}\right] \mathrm{O}_{2}$ and Their Applications to Lithium Batteries. Chem. Mater. 2006, 18, 5159-5163. [CrossRef]

126. Chen, X.; Li, D.; Mo, Y.; Jia, X.; Jia, J.; Yao, C.; Chen, D.; Chen, Y. Cathode Materials with Cross-Stack Structures for Suppressing Intergranular Cracking and High-Performance Lithium-Ion Batteries. Electrochim. Acta 2018, 261, 513-520. [CrossRef]

127. Qiu, Z.; Zhang, Y.; Huang, X.; Duan, J.; Wang, D.; Nayaka, G.P.; Li, X.; Dong, P. Beneficial Effect of Incorporating Ni-Rich Oxide and Layered over-Lithiated Oxide into High-Energy-Density Cathode Materials for Lithium-Ion Batteries. J. Power Sources 2018, 400, 341-349. [CrossRef]

128. Li, G.; Qi, L.; Xiao, P.; Yu, Y.; Chen, X.; Yang, W. Effect of Precursor Structures on the Electrochemical Performance of Ni-Rich $\mathrm{LiNi}_{0.88} \mathrm{Co}_{0.12} \mathrm{O}_{2}$ Cathode Materials. Electrochim. Acta 2018, 270, 319-329. [CrossRef]

129. Hou, P.; Li, F.; Sun, Y.; Pan, M.; Wang, X.; Shao, M.; Xu, X. Improving $\mathrm{Li}^{+}$Kinetics and Structural Stability of Nickel-Rich Layered Cathodes by Heterogeneous Inactive-Al ${ }^{3+}$ Doping. ACS Sustain. Chem. Eng. 2018, 6, 5653-5661. [CrossRef]

130. Chen, Z.; Qin, Y.; Amine, K.; Sun, Y.K. Role of Surface Coating on Cathode Materials for Lithium-Ion Batteries. J. Mater. Chem. 2010, 20, 7606-7612. [CrossRef]

131. Zhao, R.; Liang, J.; Huang, J.; Zeng, R.; Zhang, J.; Chen, H.; Shi, G. Improving the Ni-Rich LiNi ${ }_{0.5} \mathrm{Co}_{0.2} \mathrm{Mn}_{0.3} \mathrm{O}_{2}$ Cathode Properties at High Operating Voltage by Double Coating Layer of $\mathrm{Al}_{2} \mathrm{O}_{3}$ and $\mathrm{AlPO}_{4}$. J. Alloys Compd. 2017, 724, 1109-1116. [CrossRef]

132. Co, L.; Battery, M.O.; Lee, Y.; Nam, K.; Hwang, E.; Kwon, Y.; Kang, D.; Kim, S.; Song, S. Interfacial Origin of Performance Improvement and Fade for 4.6 V. J. Phys. Chem. C 2014, 118, 10631-10639.

133. Gao, H.; Maglia, F.; Lamp, P.; Amine, K.; Chen, Z. Mechanistic Study of Electrolyte Additives to Stabilize High-Voltage Cathode-Electrolyte Interface in Lithium-Ion Batteries. ACS Appl. Mater. Interfaces 2017, 9, 44542-44549. [CrossRef] [PubMed]

134. He, M.; Su, C.C.; Peebles, C.; Feng, Z.; Connell, J.G.; Liao, C.; Wang, Y.; Shkrob, I.A.; Zhang, Z. Mechanistic Insight in the Function of Phosphite Additives for Protection of $\mathrm{LiNi}_{0.5} \mathrm{Co}_{0.2} \mathrm{Mn}_{0.3} \mathrm{O}_{2}$ Cathode in High Voltage Li-Ion Cells. ACS Appl. Mater. Interfaces 2016, 8, 11450-11458. [CrossRef]

135. Nie, M.; Madec, L.; Xia, J.; Hall, D.S.; Dahn, J.R. Some Lewis Acid-Base Adducts Involving Boron Trifluoride as Electrolyte Additives for Lithium Ion Cells. J. Power Sources 2016, 328, 433-442. [CrossRef] 
136. Liu, Z.; Chai, J.; Xu, G.; Wang, Q.; Cui, G. Functional Lithium Borate Salts and Their Potential Application in High Performance Lithium Batteries. Coord. Chem. Rev. 2015, 292, 56-73. [CrossRef]

137. Nguyen, D.T.; Kang, J.; Nam, K.M.; Paik, Y.; Song, S.W. Understanding Interfacial Chemistry and Stability for Performance Improvement and Fade of High-Energy Li-Ion Battery of $\mathrm{LiNi}_{0.5} \mathrm{Co}_{0.2} \mathrm{Mn}_{0.3} \mathrm{O}_{2} / /$ Silicon-Graphite. J. Power Sources 2016, 303, 150-158. [CrossRef]

138. Jang, S.H.; Jung, K.; Yim, T. Silyl-Group Functionalized Organic Additive for High Voltage Ni-Rich Cathode Material. Curr. Appl. Phys. 2018, 18, 1345-1351. [CrossRef]

139. Shi, Y.; Zhou, X.; Yu, G. Material and Structural Design of Novel Binder Systems for High-Energy, High-Power Lithium-Ion Batteries. Acc. Chem. Res. 2017, 50, 2642-2652. [CrossRef]

(C) 2020 by the authors. Licensee MDPI, Basel, Switzerland. This article is an open access article distributed under the terms and conditions of the Creative Commons Attribution (CC BY) license (http://creativecommons.org/licenses/by/4.0/). 